\title{
Geochemistry and sedimentary provenance of the Upper Cretaceous Uberaba Formation (Southeastern Triângulo Mineiro, MG, Brazil)
}

Geoquímica e proveniência sedimentar da Formação Uberaba (sudeste do Triângulo Mineiro, MG)

\author{
Dennis Arthuso Quintão ${ }^{1 *}$, Fabrício de Andrade Caxito ${ }^{1}$, Joachim Karfunkel ${ }^{1}$, \\ Florence Rodrigues Vieira ${ }^{2}$, Hildor José Seer ${ }^{2}$, Lúcia Castanheira de Moraes ${ }^{2}$, \\ Luiz Carlos Borges Ribeiro ${ }^{3}$, Antônio Carlos Pedrosa-Soares ${ }^{1}$
}

\begin{abstract}
The campanian Uberaba Formation, which crops out around the homonymous town, is composed of greenish lithic sandstones and conglomerates with possible volcanoclastic contribution. In this unit, heavy minerals such as ilmenite, garnet, perovskite and magnetite, besides clinopyroxene, plagioclase, quartz, calcite and apatite, are found. The Uberaba Formation geochemistry is marked by high grades of $\mathrm{Ba}, \mathrm{Ta}, \mathrm{La}, \mathrm{Nb}$ and $\mathrm{Th}$, with flat (no Eu anomaly) and highly fractionated $\left(\mathrm{La}_{N} / \mathrm{Yb}_{\mathrm{N}}=\right.$ ca. 128$)$ chondrite-normalized rare earth elements. Mineral chemistry analyses of detrital garnets from the Uberaba Formation indicate the predominance of chorlomite with an affinity to crustal garnets (G3). The sedimentary provenance of the Uberaba Formation corresponds to a mixing of materials from the alkaline districts of the Alto Paranaíba and from the erosion of the Serra Geral Formation and the Canastra and Araxá groups. Diamond-producing conglomerates which crop out nearby, in Romaria, were considered by some authors as correlated to the Uberaba Formation. However, the composition of garnets recovered from those conglomerates is different, plotting in the field of mantle garnets (G9/G10). We consider, then, that those units are not correlated, and that the Uberaba Formation is not a possible source for the alluvial diamonds found in the homonymous river.
\end{abstract}

KEYWORDS: Uberaba Formation; Alkaline magmatism; Triângulo Mineiro; Provenance; Upper Cretaceous.
RESUMO: A Formaçấo Uberaba, de idade campaniana e ocorrência restrita à região da cidade homônima, é composta de arenitos líticos e conglomerados de cor esverdeada, com possivel contribuição vulcanoclástica. Nessa unidade ocorrem minerais pesados como ilmenita, granada, perovskita e magnetita, além de clinopiroxênio, plagioclásio, quartzo, calcita e apatita. A Formação Uberaba é marcada geoquimicamente por altos teores em $\mathrm{Ba}, \mathrm{Ta}, \mathrm{La}, \mathrm{Nb}$ e Th, com padröes de elementos terras raras normalizados ao condrito fortemente fracionados $\left(L a_{N} / Y b_{N}=c a\right.$. 128) $e$ planos (sem anomalia de Eu). Análises de química mineral das granadas detríticas da Formação Uberaba indicam predominância de chorlomita com afinidade com granadas crustais (G3). A proveniência sedimentar da Formação Uberaba corresponde a uma mistura de materiais de distritos alcalinos do Alto Paranaíba e derivados da erosáo da Formação Serra Geral e dos grupos Canastra e Araxá. Os conglomerados produtores de diamante que ocorrem proximamente, em Romaria, foram considerados por alguns autores como correlatos à Formação Uberaba, porém a composição das granadas retiradas desses conglomerados é bastante diferente, plotando no campo de granadas mantélicas (G9/G10). Descarta-se, dessa forma, correlação entre essas duas unidades, e a Formação Uberaba, portanto, não é uma fonte provável dos diamantes aluvionares encontrados no rio homônimo.

PALAVRAS-CHAVE: Formação Uberaba; Magmatismo Alcalino; Triângulo Mineiro; Proveniência; Cretáceo Superior.

\footnotetext{
${ }^{1}$ Universidade Federal de Minas Gerais, Programa de Pós-Graduação em Geologia - CPMTC-IGC-UFMG, Campus Pampulha, Belo Horizonte (MG), Brazil. E-mails:dennisquintao@gmail.com, boni@ufmg.br, jkarfunkel@yahoo.com, pedrosa@pq.cnpq.br

${ }^{2}$ Centro Federal de Educação Tecnológica de Minas Gerais - CEFET, Araxá (MG), Brazil. E-mails: florencerodriguesv@gmail.com, hildorster@gmail.com 2013luciam@gmail.com

${ }^{3}$ Complexo Cultural e Científico de Peirópolis, Universidade Federal do Triângulo Mineiro - UFTM, Uberaba (MG), Brazil. E-mail: lcbrmg@gmail.com

*Corresponding author.

Manuscript ID: 20170032. Received in: 01/12/2017. Approved in: 04/26/2017
} 


\section{INTRODUCTION}

The discovery of alluvial diamonds in the Triângulo Mineiro (TM) and Alto Paranaíba (AP) regions, southeast Brazil, most specifically between the cities of Coromandel and Uberaba, has called the attention of researchers on the source area and sedimentary control of these deposits. The fact that some occurrences are located in alluvial deposits of the Uberaba River (Fig. 1), which occurs in the southern portion of the TM above a specific unit denominated Uberaba Formation, has brought some attention to this unit, as in the works of Hasui (1968), Barbosa et al. (1970), Barcelos (1984), Ferreira Jr. (1996), Ferreira Jr. and Gomes (1999), and Gravina et al. (2002).

The Uberaba Formation, with a mean thickness of $70 \mathrm{~m}$ and composed of sandstones and conglomerates, was deposited at ca. $80 \mathrm{Ma}$ ago based on fossiliferous content (Huene 1939). It is stratigraphically the base of the Bauru
Group, and its sandstones show a considerable amount of detrital perovskite. Some authors interpret a volcaniclastic origin for at least part of the unit, with further sedimentary reworking (Hasui 1968, Barcelos 1984, Fulfaro \& Barcelos 1991, Goldberg 1995). Despite its importance for both the reconstruction of Cretaceous paleoenvironments and potential source for diamond-producing, the Uberaba Formation is one of the least studied units in the context of the Bauru Group.

This paper presents novel data on the Uberaba Formation, emphasizing its geological cartography, petrography, mineral chemistry and geochemical aspects. The main objective is to characterize its provenance and source areas. Besides, in the present paper, we analyze for the first time the potential of the unit as a source for the placer-type alluvial diamond deposits of the area, with respect to the great quantity of alluvial diamonds already recovered in the TM and AP (Campos 1891, Hussak 1891, Hussak

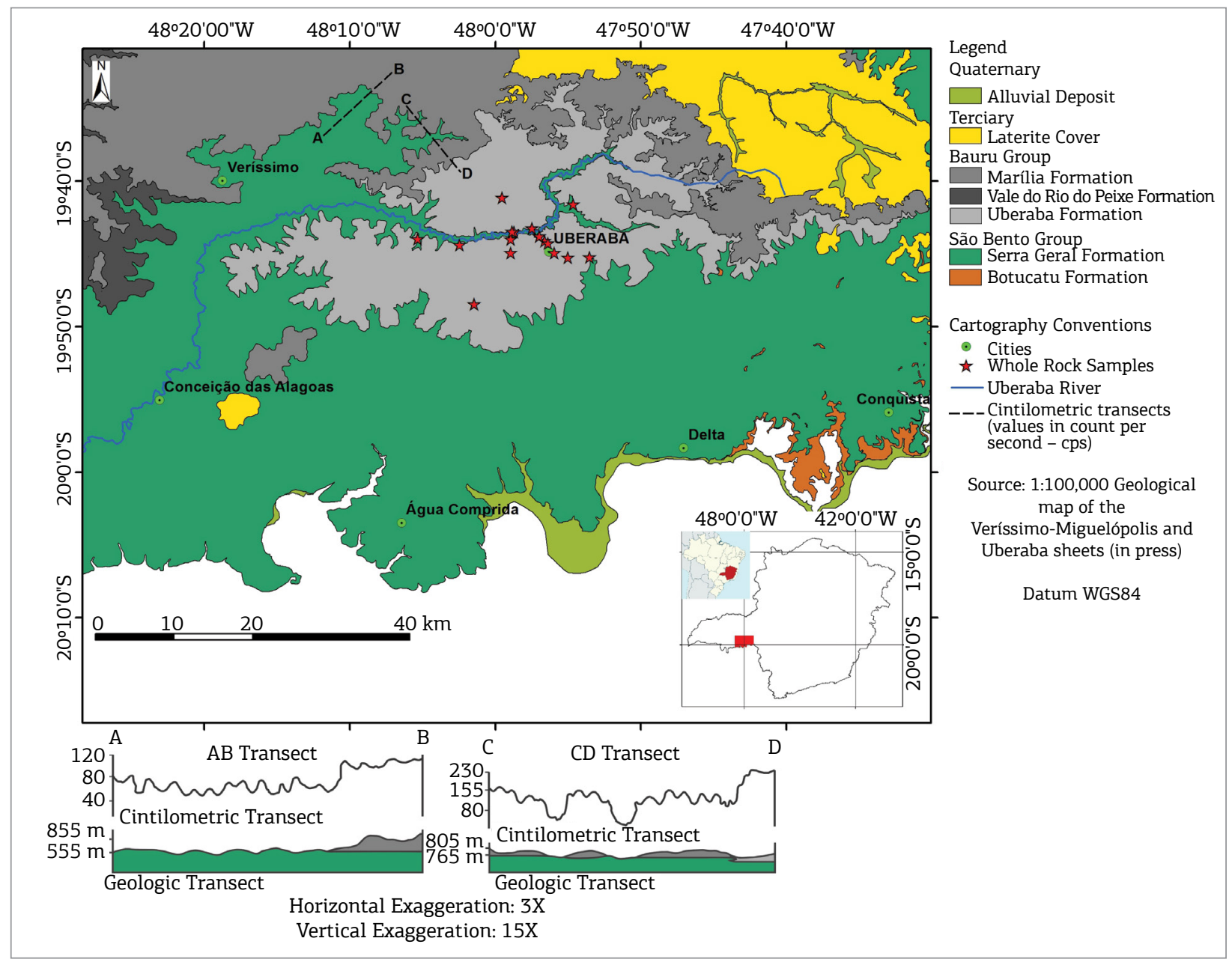

Figure 1. Integrated simplified geological map of the Veríssimo-Miguelópolis and Uberaba sheets (Ferreira et al. and Seer \& Moraes, in press), produced within the Triângulo Mineiro mapping project CODEMIG/UFMG 2015-17. Scintillometric transects A-B and C-D and the location of samples collected for whole-rock geochemistry (red stars) are also shown. 
1906, Karfunkel et al. 2014). In this respect, it is interesting that some authors correlate the Uberaba Formation to diamond-producing conglomerates, which crop out $95 \mathrm{~km}$ to the northeast, in the Romaria region (Ferreira Jr. 1996, Coelho 2010). The study of heavy minerals recovered from the Uberaba Formation, and their mineral chemistry will help in the definition of the provenance and potential for mineralization of this unit.

\section{GEOLOGICAL CONTEXT}

\section{Bauru Group and Uberaba Formation}

The Bauru Group presents approximately $370,000 \mathrm{~km}^{2}$ or ca. $20 \%$ of the Paraná Basin (Barcelos 1984, Fernandes \& Coimbra 2000), occurring in the states of Minas Gerais, Goiás, Mato Grosso do Sul, Paraná and São Paulo. This group is limited to the north by the Alto Paranaíba Arch, and corresponds to semi-arid system tract deposits, formed by alluvial fans, ephemeral fluvial systems and an endoreic palustrine zone (Milani et al. 2007).

Soares et al. (1980), based on paleontological and stratigraphic studies, suggest that the Bauru Group was deposited in the Aptian-Maastrichtian interval, as also proposed by Bertini (1993). The Uberaba Formation is considered as deposited in the Campanian (83.6 to $72.1 \mathrm{Ma}$ ), based on lithostratigraphic relationships with the Vale do Rio do Peixe and Marília formations, in addition to paleontological data (Huene 1939, Santucci \& Bertini 2001) and paleomagnetic studies of Tamrat et al. (2002).

The Uberaba Formation belongs to the lower portion of the Bauru Group, in an erosive contact upon the Serra Geral Formation (Fig. 1). This contact is marked by the presence of a polymictic conglomerate with basalt, sandstone and claystone clasts (Hussak 1906). The upper contact with the Marília Formation is considered by some authors as also abrupt, marked by a silexite level and a conglomerate rich in quartz clasts (Seer \& Moraes, in press), cimented by calcite (Barbosa 1934, Hasui 1968).

Hasui (1968), Barcelos (1984), Goldberg (1995), Ferreira Jr. (1996) and Batezelli (2003) interpret the Uberaba Formation as constituted predominantly by sedimentary rocks with volcaniclastic contribution, mostly coarse sandstones with a local greenish matrix of volcanic origin due presence of Ce oxides, arkoses and lithic sandstones, locally siltstones and mudstones (Fig. 2A), conglomerates and conglomeratic sandstones. Carbonate cementation might occur, as well as carbonate nodules. Macrofossils are common (Santucci \& Bertini 2001), as well as bioturbation (Fig. 2B), cross bedding (Fig. 2C), plane-parallel bedding and some syn-depositional deformational structures such as flame structures and convolute fold structures.

Ferreira Jr. (1996) and Ferreira Jr. and Gomes (1999) describe the presence of clay minerals such as detrital illite and authigenic esmectite in the intergranular spaces and suggest their formation from volcanic ashes. On the other hand, Goldberg (1995) proposes a process of mechanic infiltration of fine-grained sediments transported in high stand periods and deposited by decantation over the sand deposits (sieve effect).

Silva et al. (1994) suggest that detrital components of the sandstones were sourced of basalts from the Serra Geral Formation, quartzites and schists from the Canastra, Ibiá and Araxá groups, and alkaline rocks from the Alto Paranaíba region.

The depositional setting of the Uberaba Formation is a matter of high debate, and some work hypothesis have been proposed, e.g., fluvial with little transport (Hasui 1968), fluvio-deltaic (Suguio 1980), meandering (Barcelos 1989) and braided (Ferreira Jr. \& Guerra 1993, 1995, Batezelli 2003). However, a detailed sedimentological approach is necessary for this issue to be fully understood.

Besides the Uberaba Formation, the Vale do Rio do Peixe and Marília formations compose the Bauru Group in the studied area. The Vale do Rio do Peixe Formation is composed by fine to medium-grained reddish sandstones, with cross-bedded foresets of up to $3 \mathrm{~m}$ (Fernandes \& Coimbra 2000). The Marília Formation, according to Almeida \& Barbosa (1953) corresponds to conglomerates and coarse sandstones with calcite cementation, divided by Barcelos (1984) in three members: Ponte Alta (conglomerate sandstones and conglomerates, calcretes and silcretes), Serra da Galga (polimictic conglomerates with calcrete clasts) and Echaporã (fine to medium-grained sandstones). Other authors as Fernandes and Ribeiro (2015) and Batezelli and Ladeira (2016) consider only two members in this area (Serra da Galga and Ponte Alta).

The stratigraphic subdivision adopted in this paper is according Barcelos (1984) and Batezelli (2003) following the nomenclature of Vale do Rio do Peixe Formation from Fernandes and Coimbra 2000 (Fig. 3).

\section{Diamonds in the Uberaba region}

The diamond occurrences of the TM and AP regions are known for more than 250 years and correspond mostly to placer type deposits in the drainage gravels. There are some occurrences in rocks like Romaria's conglomerate and the Capacete Formation of the Mata da Corda Group (Fernandes et al. 2014). Some satellite minerals have been reported on the Uberaba Formation, such as Cr-diopside, picro-ilmenite and pyrope (Gravina et al. 2002). However, diamonds properly 
have not yet been found in the Uberaba Formation rocks, only within alluvium sediments such as along the Uberaba River. One of the authors (L.C.B.R.) saw a 9 carat diamond at the end of the 70's north of the Uberaba city recovered from gravels of the Uberaba River. According to information from garimpeiros (diggers) a $42 \mathrm{ct}$ diamond has also been recovered from an alluvial deposit. To one of the co-authors (J.K.), several diggers reported the largest recovered stone in the headwaters of the Uberaba River gravel in the 60's ties that weigh $42 \mathrm{ct}$, and a second one of $34 \mathrm{ct}$. Karfunkel et al. $(2014,2015)$ discuss and put forwards some hypotheses to explain the origin of these gems, from local sources, or transported from long distances by extrusive rocks.
Ferreira Jr. (1996) proposes that kimberlitic intrusions were important in providing those minerals. In fact, they could represent some of the sources, but not the main source because up to now no diamondiferous kimberlite or lamproite intrusions were found with a volume that could provide the ca. 40 million carats of diamonds already recovered from drains in the TM (Karfunkel et al. 2015). Besides, most kimberlites and related rocks in the TM are of small size, sterile or with non-economic diamond concentrations (Karfunkel et al. 2015). Thus, the provenance of these gems and satellite minerals from kimberlites and lamproites for this region as main suppliers is contentious.
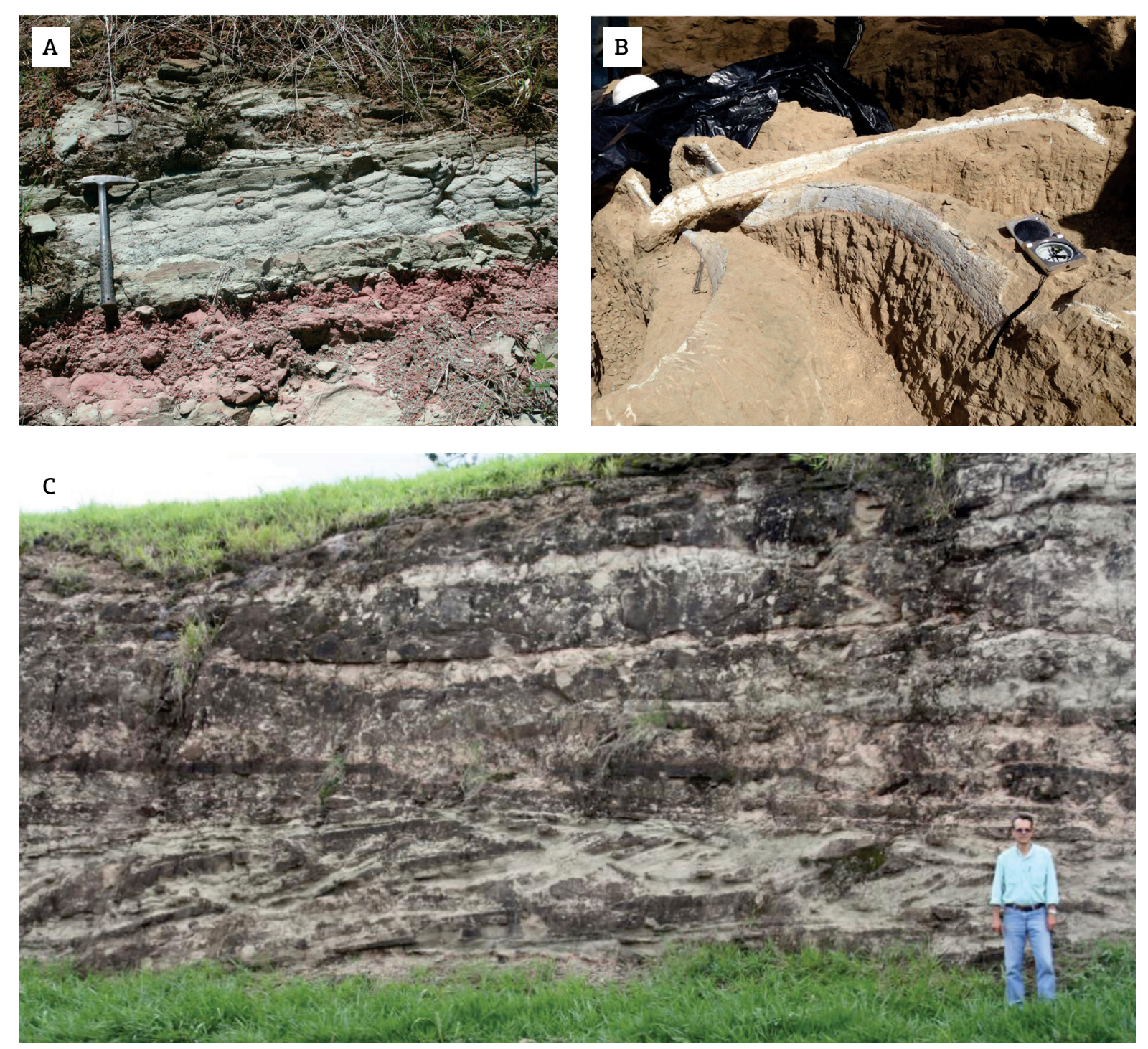

Figure 2. Field aspects of rocks from the Uberaba Formation: (A) red fine sandstone bed (below) in contact with green lithic green sandstone (above); (B) bone fossils (probably titanosaur ribs) found in excavation in the Uberaba town; (C) cross stratifications in likely channel deposits. Hammer is $42 \mathrm{~cm}$ long. 


\section{MATERIALS AND METHODS}

Fieldwork for data and sample collection was conducted within the context of the Triângulo Mineiro CODEMIG/ UFMG 2015-2017 mapping project, specifically within the context of Veríssimo/Miguelópolis and Uberaba $1: 100.000$ sheets. All of the authors were involved in the fieldwork stage. During the fieldwork, stratigraphic sections were made by L.M., H.S., D.Q. and F.C., with the collection of samples for petrographic, heavy minerals and chemical analyses.

Cartography of the Uberaba Formation was greatly aided by the utilization of aerogeophysical maps, mainly gamma spectrometric maps (U, Th and ternary K-Th-U maps in Fig. 4), from the program Levantamento Aerogeofísico do Estado de Minas Gerais 2010/2011 of CODEMIG, in a 1:500.000 scale. Also, scintillometric transects were produced by D.Q. and J.K. (Fig. 1). Those transects were made near the geological contacts between the various units in order to identify possible radiometric variations which could aid in the individualization of the units. A SC-132 hand scintillometer of Mount Sopris Instrument Co. was used for this purpose.

Separation of heavy minerals from selected samples was conducted at the Laboratório de Tratamento de Minérios, CEFET-MG - Campus Araxá. Samples were dried at $300^{\circ} \mathrm{C}$ for two hours, then crushed in a jaw crusher, sorted, and then sieved utilizing 70\# $(210 \mu \mathrm{m})$ and 120\# $(125 \mu \mathrm{m})$ sieves. Samples were panned, and then magnetite was removed using a hand magnet. Finally, acid attack with $10 \% \mathrm{HCl}$ has been carried out for 24 hours in Erlenmeyers. Heavy minerals were then separated by H.S., L.M. and F.V. using a binocular lens.

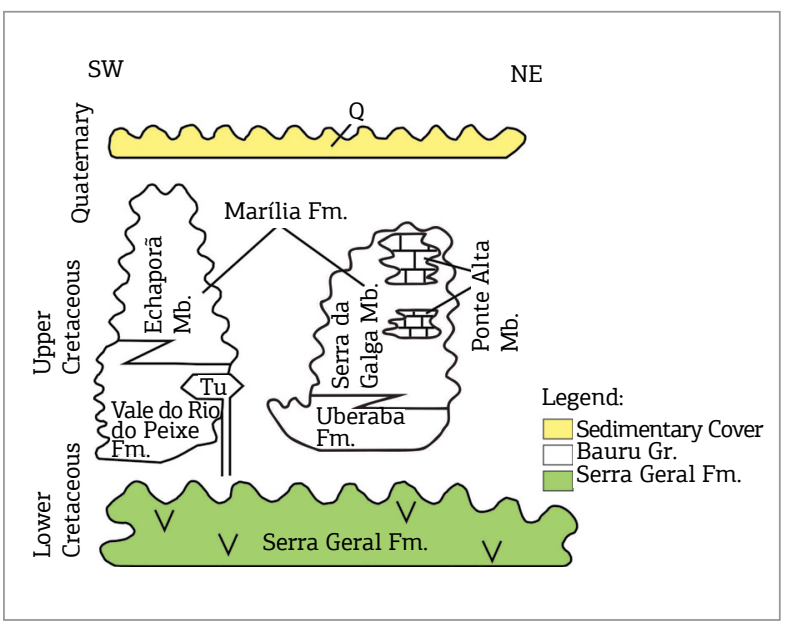

Figure 3. Lithostratigraphic chart of the Bauru basin, from Fernandes and Coimbra (2000).
Twenty-four samples were selected for petrographic analysis, from which five samples were selected for mineral chemistry analysis (samples V634, V620A and B, V631 and 7C). After covering of the polished thin sections with a fine carbon powder, they were subjected to quantitative and semi-quantitative analysis in a JEOL JXA-8900RL (WDS) microprobe at the Centro de Microscopia, Universidade Federal de Minas Gerais, using an acceleration tension of $15 \mathrm{kV}$ and a beam current of $20 \mathrm{nA}$. Twelve oxides were determined for each analyzed point, and the grades were obtained using Ian Steele and Astimex collection standards.

After crushed and pulverized, 17 samples were sent for whole rock chemistry analysis at GEOSOL Laboratories, Brazil, and two other samples were sent to ACME Analytical Laboratories Ltda., Canada (sample location in Fig. 1). Major element grades were analyzed by ICP-MS (ACME) or ICP-OES (GEOSOL), and trace element grades were analyzed by ICP-MS in both laboratories after fusion with lithium metaborate/tetraborate and digestion with diluted nitric acid. Analytical errors are within 5\% for oxides and $10-15 \%$ for trace elements. Base and precious metal grades were determined by digestion in Aqua Regia followed by ICP-MS analysis. The Loss On Ignition (LOI) was determined by the weighing difference after ignition at $1,000^{\circ} \mathrm{C}$.

\section{RESULTS}

\section{Application of geophysics in the cartography of the Uberaba Formation}

In the ternary K-Th-U gamma spectrometric map of the region an E-W trending area in the central portion exhibits high Th and $U$ contents (Fig. 4A), corresponding to the outcrop area of the Uberaba Formation (whiter colors in Fig. 4A). In the Th channel map, the Uberaba Formation is characterized by values above $23,844 \mathrm{ppm}$ (purple and pink shades in Fig. 4B), mainly due to the high perovskite content of the unit. In the $U$ channel map, values above 1,430 ppm (red and pink shades in Fig. 4C) characterize the unit.

Another resource utilized in the mapping of the Uberaba Formation is scintillometric transects (Fig. 5). During the realization of those transects, the Uberaba Formation has shown high radiometric activity, with 250-350 cps (counts per second), while basalts of the Serra Geral Formation show average values around $50 \mathrm{cps}$ and rocks of the Marília Formation around $110 \mathrm{cps}$. Thus, geophysical data improved considerably the cartography and recognition of the Uberaba Formation outcrop area. For geological mapping in flat lying 


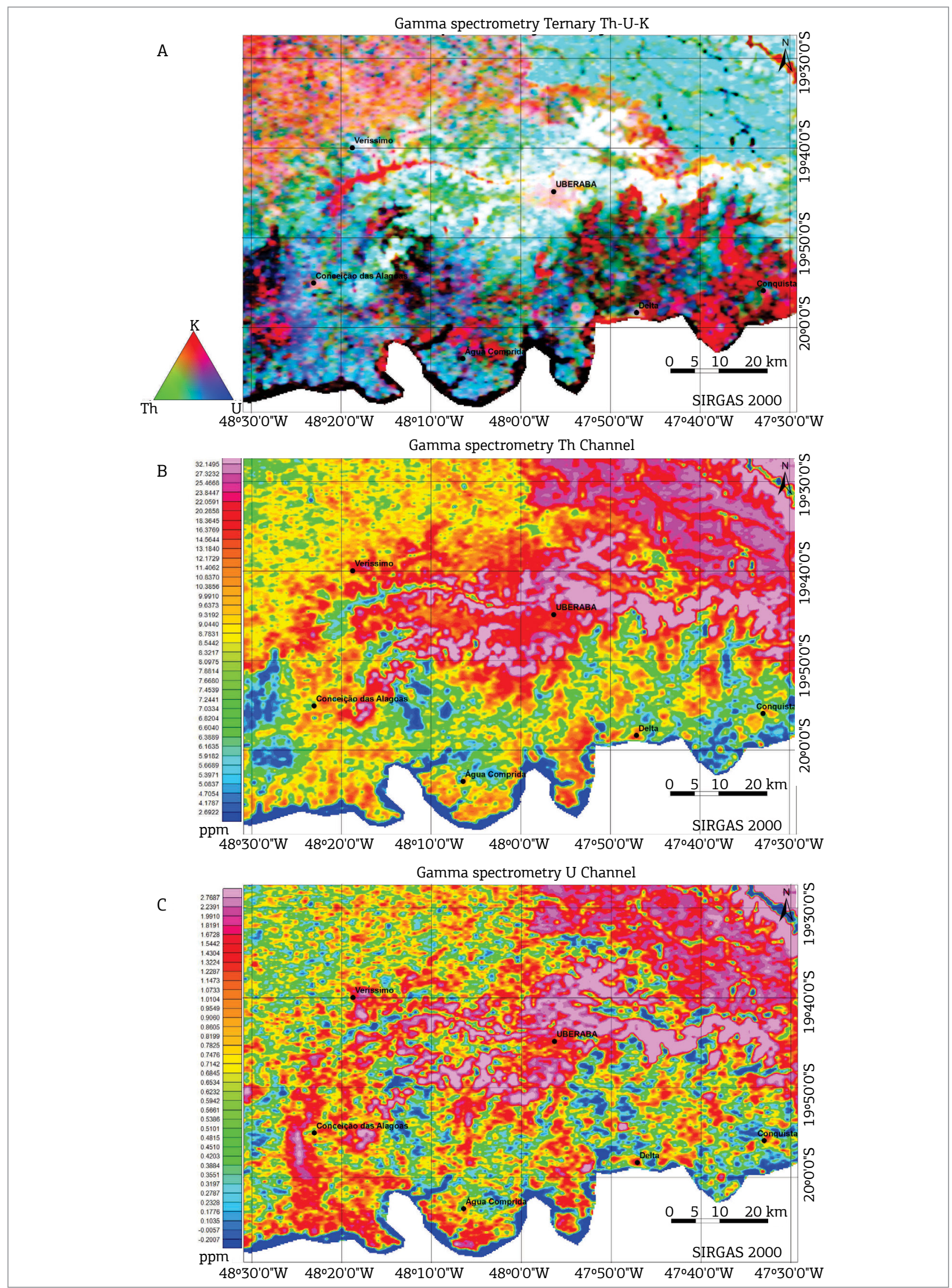

Figure 4. Geophysical maps of the Veríssimo-Miguelópolis and Uberaba sheets (data from CODEMIG, Geophysic Airborne Program 2010/2011): (A) gamma spectrometry, ternary plot Th-U-K; (B) gamma spectrometry, Th channel; (C) gamma spectrometry, U channel. 
rock sequences with different backgrounds in vast regions covered by plantations like sugar cane and soya, this auxiliary method has been of great help.

In a ternary gamma spectrometric map of the eastern TM and AP (Fig. 5), the signature of the Uberaba Formation is comparable to that of the Mata da Corda Group (Guimarães 1964, Bryon 1999, Sgarbi et al. 2003). Both units show high Th and $U$ grades as shown by the bluish colors in the map.

\section{Sedimentological aspects}

Three schematic stratigraphic columns were measured for a preliminary study of the Uberaba Formation sedimentary features. For each column, a group of sedimentary facies was described as follows.

In the MP01 column (Fig. 6), located in Randolfo Borges Junior Avenue corner with José Marçal Costa Street (190806 E/ 7815657 N; WGS84 23K), predominantly coarse facies can be recognized, marked by the occurrence of clast- and matrix-supported massive conglomerate, massive sandstone with clasts and medium-grained sandstone followed by a claystone bed. In the middle portion of the column, the sedimentary package is characterized by the presence of erosive surfaces. Above these, clast-rich sandstone and massive conglomerate have been observed, followed by a massive clast-rich sandstone that grades upwards to medium-grained sandstone. The top of the column is marked by conglomerate sandstone and medium-grained sandstone.

The MP02 column (Fig. 7), located in Randolfo Borges Junior Avenue closer to Florestan Fernandes Avenue (189948 E/ 7.816.650 N; WGS84 23 K), is characterized from base to top by normal graded facies with conglomerates grading to sandstones. Atop basalts of the Serra Geral Formation, massive matrix-supported conglomerates and sandstones with cross bedding are identified. Above an erosive surface, matrix-supported conglomerate occurs, followed by sandstone

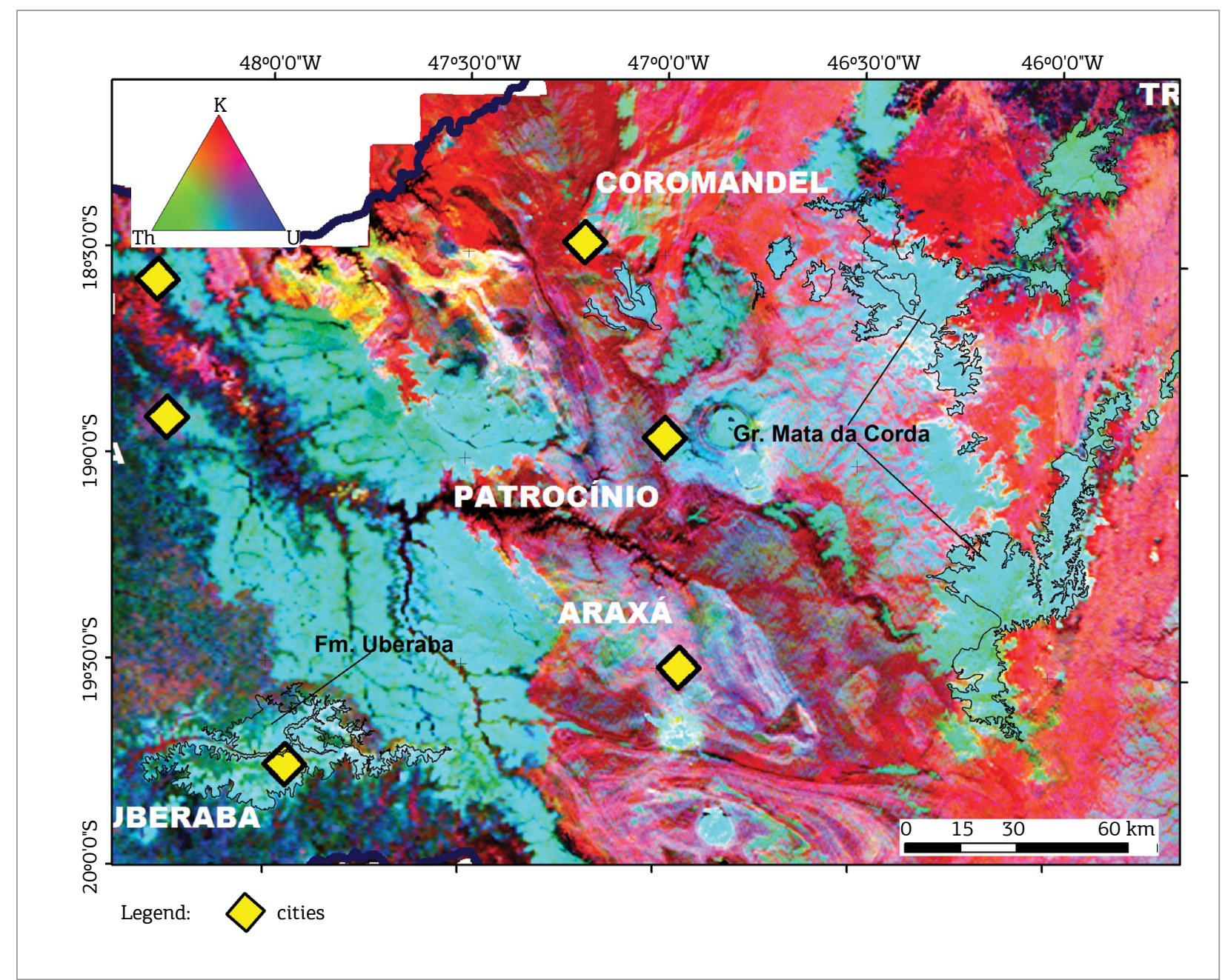

Figure 5. Ternary gamma spectrometric map of the eastern portion of the TM and AP regions, showing the outcrop areas of the Uberaba Formation and Mata da Corda Group (data from the Geophysics Airborne Program of CPRM/CODEMIG, 2006, Area 7). 
with cross bedding and claystone beds. Above a second erosive surface, another layer of clast-supported conglomerate is followed by massive and cross-bedded sandstone. In the top of the sequence, also delimited by a basal erosive surface, matrix-supported conglomerate, massive and clast-rich sandstone occurs.

The base of column FU464 (Fig. 8), located in Leopoldino de Oliveira Avenue corner with José Pimentel Camargo Street (194297 E/ 7813016 N; WGS84 23 K), is marked by a claystone bed followed by a conglomerate sandstone above an erosive surface, showing decreasing-upwards grain size and grading to medium-grained cross-bedded sandstone. The upper portion of the column is marked by another matrix-supported conglomerate covering an erosive surface.

\section{Petrography}

The sandstones of the Uberaba Formation show a mean composition of ca. $40 \%$ quartz, ca. $40 \%$ lithic fragments and ca. $15 \%$ feldspars, characterizing them as lithic sandstones

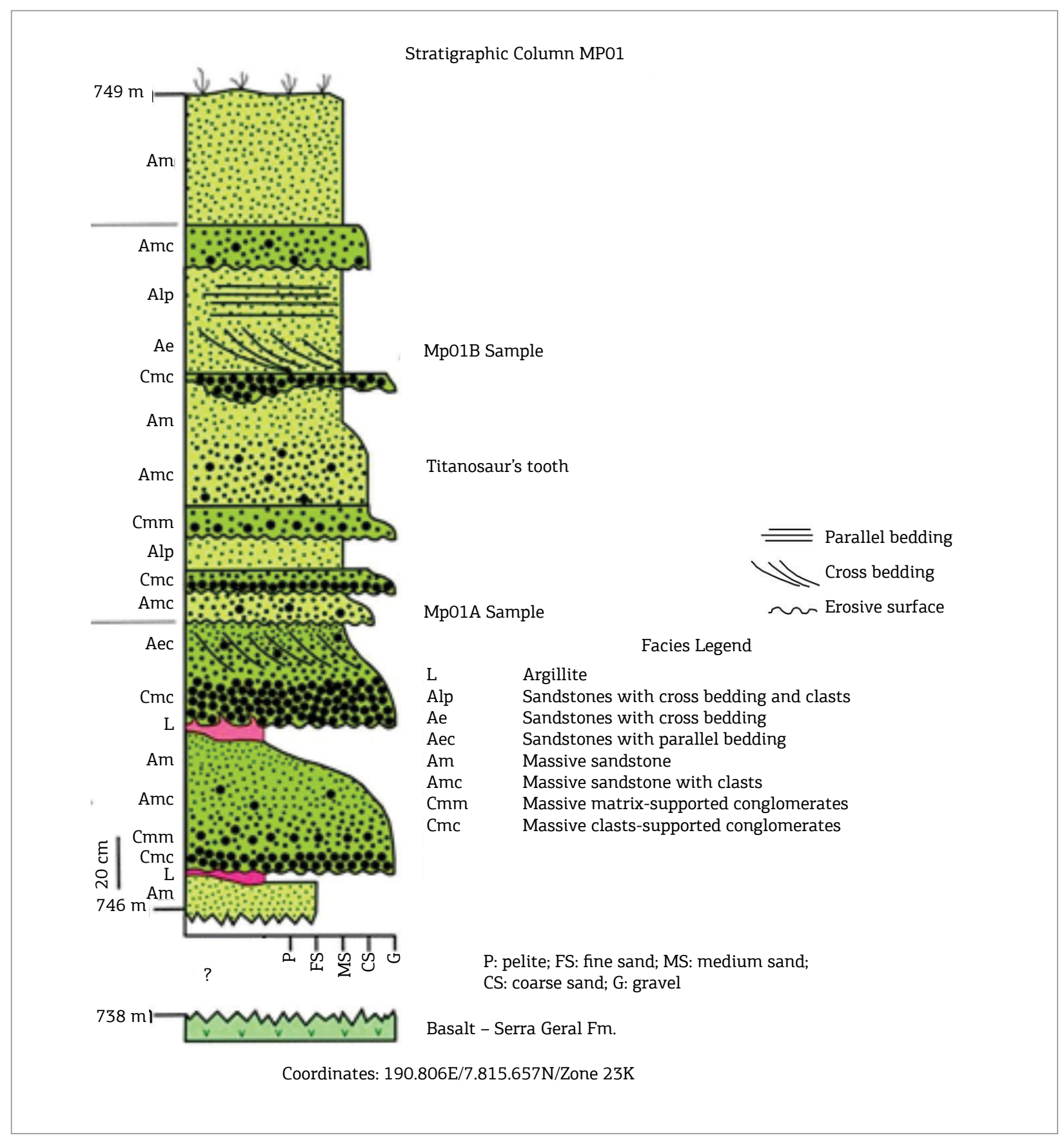

Figure 6. Stratigraphic column MP01. 


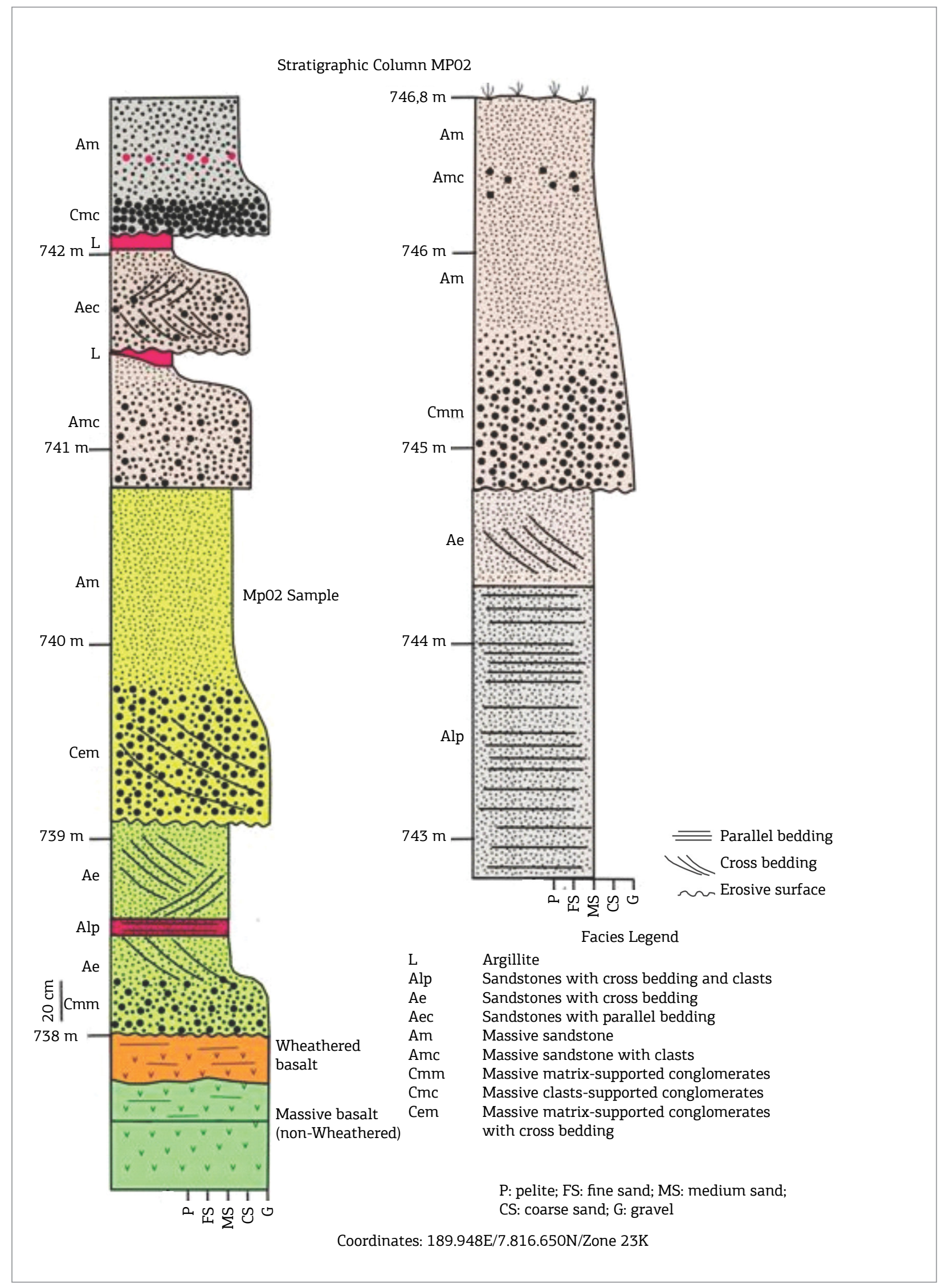

Figure 7. Stratigraphic column MP02. 
or arkoses. Accessory minerals are olivine, pyroxene, titanite, apatite, phlogopite, garnet, perovskite and opaque minerals, generally up to $5 \%$, but locally, in concentrated laminae, reaching up to $36 \%$ of the total rock.
Texturally the sandstones show a predominance of subangulous clasts of medium sphericity, with poor selection and carbonate cementation. The contact between the grains is punctual or normal, suggestive of a loose packing. Some of

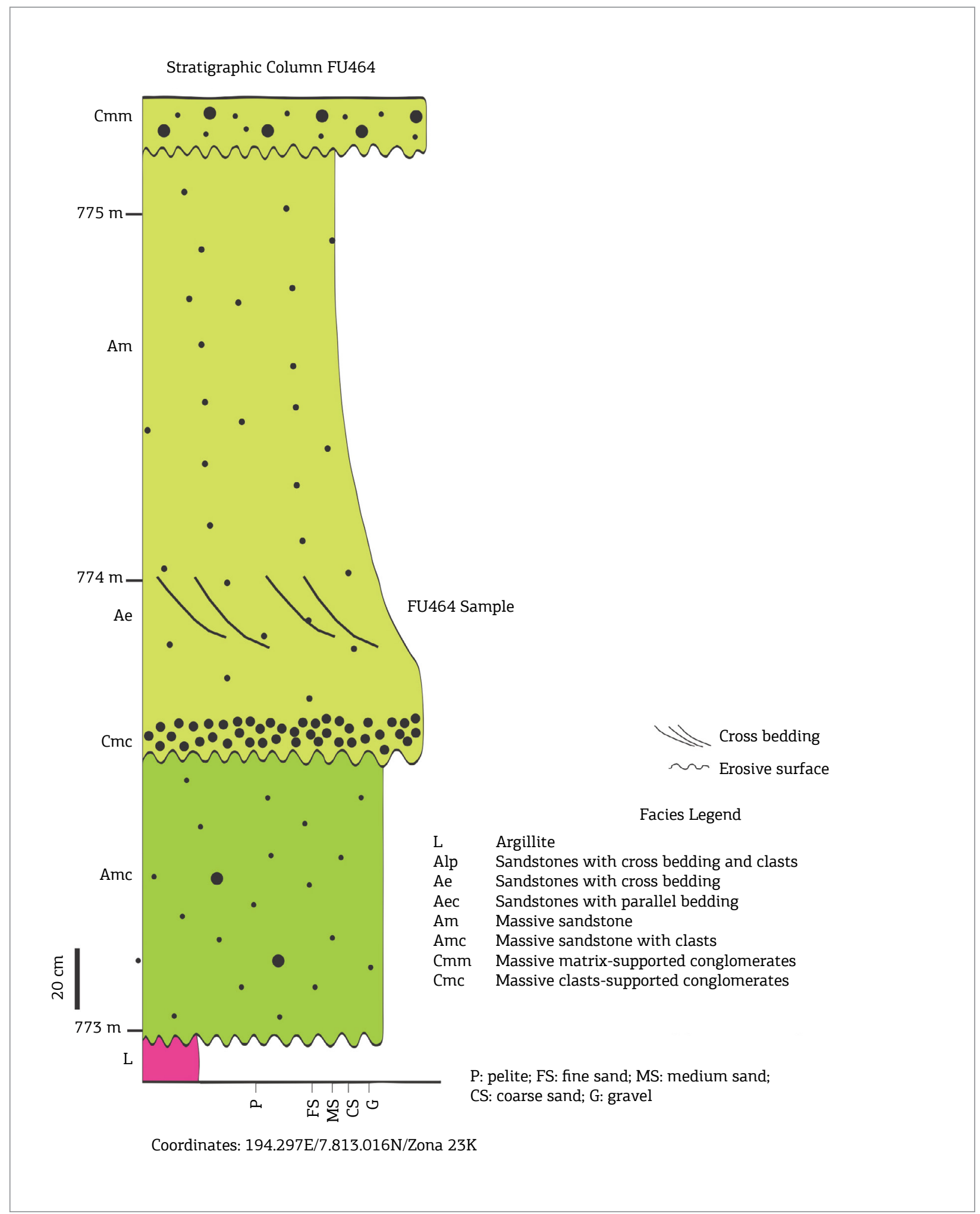

Figure 8. Stratigraphic column FU464. 
the detrital grains show chemical alterations in the borders and corrosion gulfs (Fig. 9A and B) in varying sizes, from $0.1 \mathrm{~mm}$ to $0.5 \mathrm{~mm}$.

Lithic fragments are generally constituted of basalt, quartzite, schist, phyllite and well-sorted sandstone (Fig. 9C-E).
Feldspars are usually altered through sericitization and caulinization processes. Plagioclases are more common, but alkali-feldspars also occur. It is common to identify perovskite and garnet in the heavy mineral levels (Fig. 9F). In some samples, an amorphous, very fine greenish mass of clay minerals
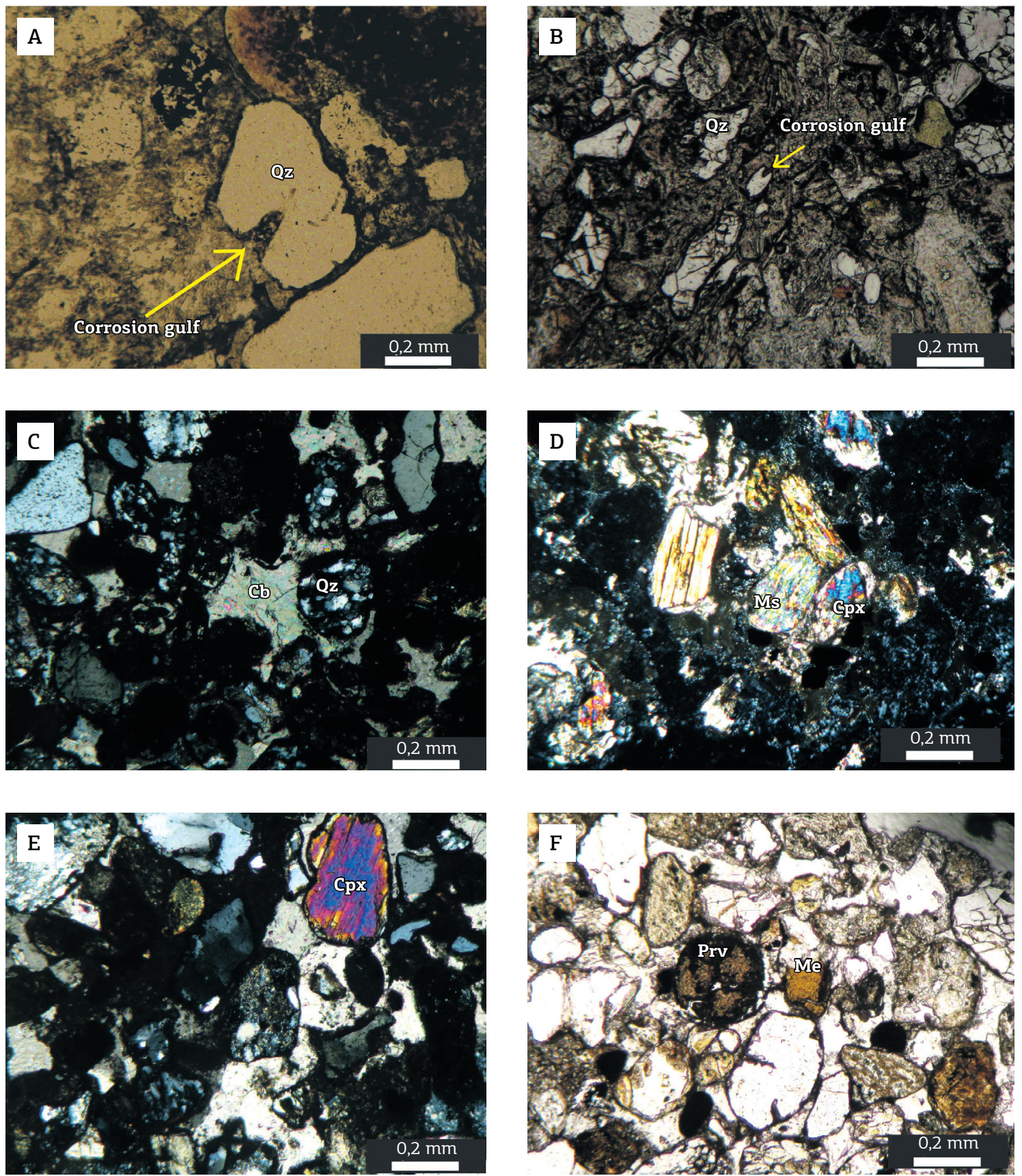

Figure 9. Photomicrographies of sandstones from the Uberaba Formation: (A and B) detail of quartz grains of probable volcanic origin, showing corrosion gulfs $(\mathrm{Qz})$, uncrossed polarizers; $(C)$ quartzite fragment $(\mathrm{Qz})$ and carbonatic cement (Cb), crossed polarizers; (D) fragment of muscovite schist (MS) and clinopyroxene (Cpx), crossed polarizers; (E) clinopyroxene ( $\mathrm{Cpx}$ ), crossed polarizers; (F) perovskite (Prv) and melanite (Me), uncrossed polarizers. 
is observed, filling the intergranular voids. This groundmass can reach up to ca. $25 \%$ of the total rock volume.

\section{Heavy minerals}

Two samples from MP02 site and three samples from MP04 were selected for separation of the heavy minerals. From those samples, magnetite, pyroxene, ilmenite, perovskite, monazite, epidote, rutile, apatite, and diopside were separated (Tab. 1). It is noteworthy that for most samples the magnetite concentration is much higher than the other minerals (ca. 75\%). The main other heavy mineral is perovskite (ca. $70 \%$ of the clean concentrates), followed by pyroxene with ca. $20 \%$ and ilmenite around $7 \%$. Other minerals such as monazite, epidote, rutile and apatite show minor contributions or are lacking in some samples.

\section{Mineral Chemistry}

Through quantitative and semi-quantitative (EDS) microprobe analysis a great variety of detrital minerals from the Uberaba Formation were characterized, such as ilmenite, perovskite, phlogopite, andradite, pumpellyite, augite and richterite, sanidine and diopside (Tab. 2). Semi-quantitative EDS analyses (Tab. 3) aided in the characterization of other minerals such as titanite, celadonite, zircon, apatite, anatase, rutile, phlogopite, allanite, illite, muscovite, glauconite and dolomite.

Analyses of perovskite (Tab. 2) were always performed in the nucleus of the grains, due to its small size. The analyzed perovskites are close to the ideal formule (final member $\mathrm{CaTiO}_{3}$ with ca. 29.48\% Ca and 35.22\% Ti).
Low grades of $\mathrm{Na}$, between 0.04 and $0.62 \%$, suggest low concentration of components such as loparite $\left(\mathrm{NaCeTi}_{2} \mathrm{O}_{6}\right)$ and/or lueshite $\left(\mathrm{Na}_{2} \mathrm{Nb}_{2} \mathrm{O}_{6}\right)$. Considerable amounts of $\mathrm{Fe}$, between 0.64 and $1.41 \%$, might be related to solid solution of latrappite $\left(\mathrm{CaNb}_{0.5} \mathrm{Fe}_{0.5} \mathrm{O}_{3}\right)$. Th can reach up to $0.36 \%$ (Tab. 2), which reflects the characteristic gamma spectrometric responses of the Uberaba Formation (Fig. 4B). U, on the other hand, might be more correlated to celadonite in the rock matrix.

Detrital garnets of the Uberaba Formation are typically enriched in $\mathrm{Ca}$ (22.41 to $24.36 \%$ ), Fe (19.58 to $20.34 \%$ ) and $\mathrm{Ti}(2.12$ to $3.54 \%)$, and show low $\mathrm{Al}(0.22$ to $0.40 \%)$, $\mathrm{Cr}(0.04$ to $0.22 \%)$ and $\mathrm{Mn}(0.02$ to $0.08 \%)$, mostly classified as andradite. $\mathrm{Ti}$ and $\mathrm{Fe}$ enrichment of those garnets allows to further classify then as the andradite subtypes, mostly schorlomite and melanite (Deer et al. 1992).

The most common detrital mica of the Uberaba Formation is phlogopite. Chemistry analyses close between $77.23 \mathrm{e}$ $91.25 \%$ because of the water preset in their mineral structure, which is not considered during the analyses. The phlogopites show $\mathrm{Mg}$ amounts between 11.74 and $16.84 \%$, Fe between 4.32 and 6.64\%, Al between 3.97 and 6.678\%, and, lastly, Ti between 1.14 and $1.92 \%$ (Tab. 2). The majority of the phlogopites analyses belong to a solid solution series between tetra-ferriphlogopite and phlogopite.

\section{Whole rock geochemistry}

Nineteen samples were analyzed for whole rock geochemistry, and results are shown in Tables 4 and 5. The spatial distribution of those samples within the Uberaba Formation is shown in Fig. 1.

Table 1. Heavy mineral concentrated from Uberaba Formation.

\begin{tabular}{|c|c|c|c|c|c|c|}
\hline & & \multicolumn{5}{|c|}{ Samples } \\
\hline & Mineral (\%) & MP02A & MP02C & MP04A & MP04B & MP04D \\
\hline & Heavy mineral total mass (g) & 1.9 & 5.89 & 16.47 & 13.81 & 23.29 \\
\hline \multirow{2}{*}{ Heavy Minerals } & Magnetite (\%) & 75.79 & 74.02 & 79.05 & 71.04 & 78.02 \\
\hline & Clean Concentrate (\%) & 24.21 & 25.98 & 20.95 & 28.96 & 21.98 \\
\hline \multirow{8}{*}{ Clean Concentrate } & Pyroxene & 9.84 & 19.39 & 24.52 & 20.43 & 25.78 \\
\hline & Illmenite & 2.76 & 10.32 & & & 0.15 \\
\hline & Perovskite & 85.53 & 61.56 & 75.3 & 79.56 & 72.85 \\
\hline & Monazite & & & 0.16 & & 0.9 \\
\hline & Epidote & 0.3 & & & & \\
\hline & Rutile & 1.53 & & & & \\
\hline & Apatite & & 7.29 & & & \\
\hline & Diopside & & 1.42 & & & 0.3 \\
\hline
\end{tabular}


Samples show overall low $\mathrm{SiO}_{2}(25.15$ to $53.88 \%)$ and $\mathrm{Al}_{2} \mathrm{O}_{3}$ content $(2.70$ to $6.71 \%$ ), and relatively high contents of $\mathrm{CaO}$ (2.34 to $29.18 \%$ ), $\mathrm{K}_{2} \mathrm{O}$ (2.85 to 6.97\%), $\mathrm{Fe}_{2} \mathrm{O}_{3}$
(7.99 to $17.36 \%$ - locally reaching abnormal values up to $30 \%$ ) and $\mathrm{TiO}_{2}$ (3.82 to $13.23 \%$ - reaching up to $24 \%$ ). $\mathrm{P}_{2} \mathrm{O}_{5}$ grades are between 0.58 and $1.48 \%, \mathrm{MgO}$ between

Table 2. Mineral Chemistry from electron microprobe (\%wt).

\begin{tabular}{|c|c|c|c|c|c|c|c|c|c|c|c|c|c|}
\hline $\mathrm{Na}$ & $\mathbf{T i}$ & Th & Si & $\mathrm{Cr}$ & $\mathbf{U}$ & Mg & $\mathrm{Fe}$ & $\mathrm{Ca}$ & Al & Mn & $\mathbf{K}$ & $\begin{array}{c}\text { Total } \\
(\%)\end{array}$ & Minerals \\
\hline 0.02 & 3.37 & 0 & 14.99 & 0.06 & 0.12 & 0.46 & 20.06 & 24.36 & 0.22 & 0.22 & 0.02 & 63.88 & Andradite \\
\hline 0.01 & 3.54 & 0 & 14.94 & 0.08 & 0 & 0.55 & 19.58 & 24.23 & 0.4 & 0.18 & 0.01 & 63.53 & Andradite \\
\hline 0.07 & 2.38 & 0 & 15.72 & 0.05 & 0 & 0.42 & 20.11 & 22.41 & 0.27 & 0.11 & 0.01 & 61.54 & Andradite \\
\hline 0.02 & 2.12 & 0 & 16.73 & 0.02 & 0.06 & 0.35 & 20.34 & 23.08 & 0.27 & 0.04 & 0 & 63.01 & Andradite \\
\hline 0.75 & 0.67 & 0 & 25.36 & 0 & 0.03 & 9.68 & 3.55 & 16.95 & 0.07 & 0.06 & 0.01 & 57.13 & Augite \\
\hline 0.05 & 1.69 & 0 & 15.89 & 0.07 & 0.73 & 11.74 & 5.78 & 0.51 & 3.97 & 0.3 & 3.22 & 43.94 & Phlogopite \\
\hline 0.08 & 1.19 & 0.09 & 16.99 & 0 & 0.61 & 15.72 & 4.53 & 0.65 & 6.16 & 0.26 & 3.1 & 49.38 & Phlogopite \\
\hline 0.04 & 1.92 & 0 & 16.16 & 0 & 0 & 15.24 & 6.64 & 1.21 & 5.22 & 0.11 & 4.46 & 51 & Phlogopite \\
\hline 0.05 & 1.14 & 0 & 17.73 & 0.02 & 0.49 & 16.84 & 4.33 & 0.54 & 6.68 & 0.29 & 2.89 & 51 & Phlogopite \\
\hline 0.23 & 0.32 & 0 & 24.51 & 0 & 0.08 & 10.86 & 2.57 & 17.82 & 0.08 & 0.08 & 0 & 56.55 & Diopside \\
\hline 0.07 & 0.07 & 0.01 & 23.67 & 0 & 0 & 0.36 & 0.61 & 0.11 & 10.63 & 0 & 5.97 & 41.51 & Illite \\
\hline 0.06 & 30.04 & 0 & 0 & 0.25 & 0 & 5.3 & 30.3 & 0.06 & 0 & 0.7 & 0.01 & 66.71 & Ilmenite \\
\hline 0.02 & 33.55 & 0.01 & 0.03 & 0.1 & 0.05 & 7.01 & 17.94 & 0.65 & 0 & 2.99 & 0.05 & 62.4 & Ilmenite \\
\hline 0.1 & 0 & 0 & 25.98 & 0 & 0 & 0.14 & 0.41 & 0.09 & 10.17 & 0 & 8.3 & 45.19 & Muscovite \\
\hline 1 & 32.86 & 0.36 & 0 & 0 & 0 & 0 & 0.97 & 23.1 & 0.02 & 0 & 0.01 & 58.32 & Perovskite \\
\hline 0.63 & 33.92 & 0.15 & 0.02 & 0 & 0.04 & 0 & 0.72 & 24.71 & 0.03 & 0.02 & 0.02 & 60.25 & Perovskite \\
\hline 0.6 & 33.77 & 0.21 & 0.02 & 0 & 0.01 & 0.01 & 0.72 & 25.46 & 0.01 & 0 & 0.01 & 60.83 & Perovskite \\
\hline 0.21 & 34.72 & 0.16 & 0.01 & 0 & 0 & 0 & 0.76 & 28.06 & 0.06 & 0 & 0.02 & 63.99 & Perovskite \\
\hline 0.04 & 34.13 & 0.03 & 0.03 & 0 & 0.04 & 0.02 & 1.33 & 28.87 & 0.09 & 0.06 & 0.01 & 64.65 & Perovskite \\
\hline 0.05 & 33.8 & 0.04 & 0.04 & 0 & 0 & 0.02 & 1.23 & 29 & 0.07 & 0 & 0.02 & 64.26 & Perovskite \\
\hline 0.06 & 33.08 & 0.01 & 0.06 & 0.01 & 0.01 & 0.03 & 1.41 & 28.57 & 0.12 & 0.01 & 0.02 & 63.39 & Perovskite \\
\hline 0.26 & 34.29 & 0.15 & 0.03 & 0.07 & 0 & 0 & 0.72 & 28.51 & 0.02 & 0 & 0.02 & 64.07 & Perovskite \\
\hline 0.1 & 33.98 & 0.02 & 0.06 & 0.02 & 0 & 0.03 & 1.03 & 28.68 & 0.06 & 0.06 & 0.04 & 64.08 & Perovskite \\
\hline 0.23 & 35.7 & 0 & 0.01 & 0 & 0.06 & 0 & 0.78 & 28.47 & 0.02 & 0.03 & 0.01 & 65.31 & Perovskite \\
\hline 0.56 & 34.06 & 0.06 & 0.01 & 0 & 0 & 0 & 0.74 & 25.93 & 0.03 & 0.03 & 0.02 & 61.44 & Perovskite \\
\hline 0.55 & 34.65 & 0.13 & 0.02 & 0.02 & 0 & 0.02 & 0.64 & 26.27 & 0.01 & 0.01 & 0.01 & 62.33 & Perovskite \\
\hline 0.01 & 0.19 & 0 & 17.68 & 0.02 & 0 & 0.01 & 6.47 & 17.06 & 14.97 & 0.13 & 0.01 & 56.55 & Pumpellyite \\
\hline 0 & 0.08 & 0 & 46.27 & 0 & 0 & 0 & 0 & 0.01 & 0.01 & 0.04 & 0 & 46.41 & Quartz \\
\hline 6.62 & 0.54 & 0.01 & 26.44 & 0.03 & 0 & 2.57 & 18.93 & 5.78 & 0.09 & 0.28 & 0.01 & 61.29 & Amphibole \\
\hline 5.46 & 0.37 & 0.02 & 24.2 & 0 & 0.03 & 2.61 & 16.96 & 6.77 & 0.06 & 0.45 & 0.02 & 56.94 & Amphibole \\
\hline 0.34 & 0 & 0.04 & 28.29 & 0.05 & 0 & 0 & 0.02 & 0.01 & 10.08 & 0 & 11.96 & 50.78 & Sanidine \\
\hline 0.11 & 25.37 & 0.03 & 6.08 & 0.16 & 0.08 & 0.07 & 13.74 & 7.66 & 0.03 & 0.67 & 0.04 & 54.03 & Titanite \\
\hline 0.1 & 23.23 & 0 & 14.74 & 0 & 0.02 & 0 & 1.31 & 20.03 & 0.08 & 0.05 & 0.01 & 59.56 & Titanite \\
\hline
\end{tabular}


3.59 and $11.38 \%)$ and $\mathrm{Na}_{2} \mathrm{O}(0.08$ to $0.28 \%), \mathrm{MnO}(0.14$ to $0.36 \%)$ and $\mathrm{Cr}_{2} \mathrm{O}_{3}(0.05$ to $0.77 \%)$ are low.

Chondrite-normalized rare earth element (REE) patterns of the samples are characterized by a strong fractioning of the light rare earths (LREE) relative to the heavy rare earths (HREE), with $\mathrm{La}_{\mathrm{N}} / \mathrm{Yb}_{\mathrm{N}}$ around 128 and $\mathrm{La}_{\mathrm{N}} /$ $\mathrm{Lu}_{\mathrm{N}}$ around 154. No relevant Eu anomalies are found, and the mean value of $\mathrm{Eu} / \mathrm{Eu}^{*}$ is 0.89 . Thus, the chondrite-normalized patterns are flat with a steep incline towards HREE (LREE - enriched).

Chondrite-normalized (Thompson 1982) incompatible element plots for the Uberaba Formation (Fig. 10A) show a distinctive enrichment in $\mathrm{Ta}-\mathrm{Nb}$ (positive $\mathrm{Ta}-\mathrm{Nb}$ anomaly) and also Th enrichment (due to the presence of perovskite). $\mathrm{P}$ and $\mathrm{Sr}$ show, on the other hand, negative anomalies. North American Shale Composite (NASC)-normalized patterns (Taylor \& McLennan 1995) present the same anomalies verified on the chondrite-normalized plots (Fig. 10B and 10C).
In the plots of Figs. 11 and 12, besides the samples of the Uberaba Formation, the fields which correspond to the plotting area of the alkaline complexes of the AP (Tapira, Araxá, Cataláo I, Serra Negra and Salitre) are also plotted for comparison. In general, samples from the Uberaba Formation plot within the patterns of the AP complexes in Fig. 11, and there is a high overlap between the complexes, generally showing highly fractionated LREE and a positive $\mathrm{Nb}-\mathrm{Ta}$ anomaly. The patterns which are closer to the Uberaba Formation are those of Tapira and Cataláo. Fig. 12A shows a bi-variant plot of $\mathrm{SiO}_{2} \times \mathrm{MgO}$. Those two variables are not correlated, and $\mathrm{MgO}$ is constant with higher $\mathrm{SiO}_{2}$. In this diagram, some samples plot within the Serra Negra / Salitre and Tapira / Araxá fields, but away from Cataláo I.

Figure 12B corresponds to a diagram proposed by Foley et al. (1987), which utilize $\mathrm{CaO}$ and $\mathrm{Al}_{2} \mathrm{O}_{3}$ grades. The Uberaba Formation samples are characterized by low $\mathrm{Ca}$

Table 3. Mineral Chemistry from energy dispersive X-ray detector (EDS) analyzes (\%wt).

\begin{tabular}{|c|c|c|c|c|c|c|c|c|c|c|c|c|c|c|c|c|}
\hline $\mathrm{Na}$ & $\mathbf{T i}$ & $\mathbf{S i}$ & $\mathrm{Cr}$ & Mg & $\mathbf{F e}$ & $\mathrm{Ca}$ & Al & Mn & $\mathbf{K}$ & $\mathbf{P}$ & $\mathrm{Ba}$ & C & $\mathrm{Zr}$ & S & $\mathrm{Ce}$ & Mineral \\
\hline 0 & 0 & 15.75 & 0 & 0 & 8.02 & 6.24 & 0 & 0 & 0 & 4.15 & 0 & 0 & 0 & 0 & 17.62 & Allanite \\
\hline 0 & 3.45 & 22.74 & 0 & 6.63 & 3.25 & 0 & 5.54 & 0 & 7.39 & 0 & 0 & 0 & 0 & 0 & 0 & $\begin{array}{l}\text { Alumino } \\
\text { Celadonite }\end{array}$ \\
\hline 0 & 59.9 & 0 & 0 & 0 & 0 & 0 & 0 & 0 & 0 & 0 & 0 & 0 & 0 & 0 & 0 & $\begin{array}{l}\text { Anatase } \\
\text { or Rutile }\end{array}$ \\
\hline 0 & 0 & 0 & 0 & 0 & 0 & 39.27 & 0 & 0 & 0 & 16.58 & 0 & 0 & 0 & 0 & 0 & Apatite \\
\hline 0 & 0 & 0 & 0 & 0 & 0 & 0 & 0 & 0 & 0 & 0 & 46.14 & 0 & 0 & 23.35 & 0 & Barite \\
\hline 0 & 0 & 21.59 & 0 & 10.3 & 0 & 0 & 7.18 & 0 & 7.09 & 0 & 0 & 0 & 0 & 0 & 0 & Biotite \\
\hline 0 & 0 & 27.65 & 0 & 5.55 & 5.11 & 0 & 2.78 & 0 & 7.65 & 0 & 0 & 0 & 0 & 0 & 0 & Celadonite \\
\hline 0 & 0 & 22.93 & 0 & 7.31 & 9.42 & 0 & 3.85 & 0 & 6.04 & 0 & 0 & 0 & 0 & 0 & 0 & Celadonite \\
\hline 0 & 0 & 0 & 0 & 20.44 & 0 & 32.32 & 0 & 0 & 0 & 0 & 0 & 1.54 & 0 & 0 & 0 & Dolomite \\
\hline 0 & 0 & 21.44 & 0 & 16.61 & 0 & 0 & 7.02 & 0 & 0 & 0 & 0 & 0 & 0 & 0 & 0 & Phlogopite \\
\hline 0 & 0 & 23.07 & 0 & 7.27 & 9.36 & 0 & 3.82 & 0 & 6 & 0 & 0 & 0 & 0 & 0 & 0 & Glauconite \\
\hline 0 & 0 & 21.02 & 0 & 2.35 & 0 & 0 & 17.05 & 0 & 5.53 & 0 & 0 & 0 & 0 & 0 & 0 & Illite \\
\hline 0 & 0 & 21.31 & 0 & 3.06 & 0 & 0 & 16.58 & 0 & 7.27 & 0 & 0 & 0 & 0 & 0 & 0 & Illite \\
\hline 0 & 0 & 21.2 & 0 & 0 & 0 & 0 & 15.76 & 0 & 9.42 & 0 & 0 & 0 & 0 & 0 & 0 & Muscovite \\
\hline 0 & 0 & 28.4 & 0 & 0 & 0 & 0 & 10.01 & 0 & 10.1 & 0 & 0 & 0 & 0 & 0 & 0 & Sanidine \\
\hline 0 & 12.98 & 19.55 & 0 & 0 & 0 & 21.84 & 0 & 0 & 0 & 0 & 0 & 0 & 0 & 0 & 0 & Titanite \\
\hline 0 & 0 & 21.37 & 0 & 0 & 0 & 0 & 0 & 0 & 0 & 0 & 0 & 0 & 34.82 & 0 & 0 & Zircon \\
\hline
\end{tabular}


and high $\mathrm{Al}_{2} \mathrm{O}_{3}$ as compared with the alkaline complexes, although the Serra Negra/Salitre complexes plot closer to the samples.

Figure $12 \mathrm{C}$ correlates the quantities of $\mathrm{TiO}_{2}$ with $\mathrm{SiO}_{2}$. This diagram shows elevated values for the Uberaba Formation, plotting closer to the Serra Negra/Salitre complexes, compared to the other alkaline complexes. The elevated $\mathrm{SiO}_{2}$ and $\mathrm{TiO}_{2}$ contents can again be correlated with detrital input from sandstones, quartzites and schists of the basement $\left(\mathrm{SiO}_{2}\right)$ and alkaline complexes $\left(\mathrm{TiO}_{2}\right)$.

Unlike major element-based diagrams, a trace-element diagram using the $\mathrm{Th} / \mathrm{Yb}$ vs. Ta/ $\mathrm{Yb}$ ratios (Wilson 1989) show a high geochemical affinity of the Uberaba Formation to the AP alkaline complexes, with an enriched-mantle like composition (Fig. 12D).

\section{DISCUSSION}

In order to discuss the possible source areas of the Uberaba Formation, we consider here three main distinct sources, two of them included in the nearby basement (Serra Geral Formation and Proterozoic units of the Canastra and Araxá groups), and the third represented by the alkaline-carbonatite complexes of the AP (Fig. 13). Rocks on the AP became exposed and began suffering erosion during the Meso/Neocretaceous with a positive reactivation (Costa 1963, Hasui 1968, Sad 1970). This reactivated high probably provided the detrital contribution during the Cretaceous sedimentation on the northeastern part of the Bauru Basin.

The Mata da Corda Group is another very important unit of the AP (Fig. 13). This group is composed of alkaline volcanics, pyroclastics and epiclastic rocks, with lamproitic,

Table 4. Whole rock analysis - Major elements (\%wt).

\begin{tabular}{|c|c|c|c|c|c|c|c|c|c|c|c|c|c|c|}
\hline & 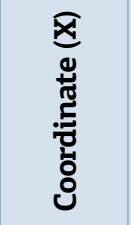 & 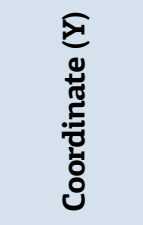 & 导 & @્ & ర్ & $O^{m}$ & $\begin{array}{l}O^{m} \\
\mathcal{O}^{n} \\
w^{n}\end{array}$ & $0_{N}^{N}$ & 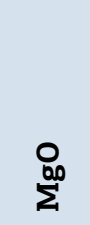 & $\stackrel{\text { 일 }}{\Sigma}$ & $\stackrel{0}{0}_{\tilde{Z}^{N}}^{\tilde{Z}^{2}}$ & $\begin{array}{l}O_{n}^{n} \\
a_{1}^{n}\end{array}$ & $\stackrel{\circ}{N}^{N}$ & $\stackrel{\rho}{\mathrm{H}}^{N}$ \\
\hline $7 C$ & 191484 & 7815082 & $23 \mathrm{~K}$ & 4.86 & 10.95 & 0.13 & 15.85 & 5.89 & 9.7 & 0.19 & 0.12 & 1.49 & 42.35 & 8.48 \\
\hline FU442 & 194843 & 7819800 & $23 K$ & 4.85 & 11.12 & 0.26 & 12.09 & 5.71 & 8.99 & 0.15 & 0.18 & 0.69 & 48.92 & 7.05 \\
\hline FU460 & 191898 & 7814786 & $23 \mathrm{~K}$ & 6.11 & 27.04 & 0.12 & 8.69 & 6.15 & 4.99 & 0.16 & 0.18 & 0.71 & 41.79 & 4.07 \\
\hline FU464 & 194297 & 7813016 & $23 \mathrm{~K}$ & 5.58 & 9.45 & 0.25 & 13.34 & 6.06 & 7.48 & 0.17 & 0.28 & 0.89 & 49.14 & 7.36 \\
\hline HD04 & 196919 & 7813106 & $23 \mathrm{~K}$ & 5.68 & 9.37 & 0.21 & 13.55 & 6.53 & 8.14 & 0.19 & 0.24 & 0.84 & 48.39 & 6.86 \\
\hline HD05 & 192647 & 7813608 & $23 \mathrm{~K}$ & 4.66 & 10.49 & 0.17 & 15.79 & 6.02 & 10.25 & 0.19 & 0.17 & 0.92 & 43 & 8.35 \\
\hline MP01A & 190806 & 7815657 & $23 \mathrm{~K}$ & 4.55 & 8.84 & 0.11 & 13.46 & 5.42 & 9.89 & 0.15 & 0.11 & 0.63 & 49.65 & 7.2 \\
\hline MP01B & 190806 & 7815657 & $23 \mathrm{~K}$ & 2.84 & 12.44 & 0.11 & 15.65 & 4.59 & 9.59 & 9.59 & 0.1 & 0.85 & 31.56 & 12.69 \\
\hline MPO2 & 189948 & 7816650 & $23 \mathrm{~K}$ & 4.78 & 25.7 & 0.05 & 7.99 & 4.71 & 7.5 & 0.15 & 0.16 & 0.76 & 44.38 & 3.82 \\
\hline MP04 & 187457 & 7815942 & $23 \mathrm{~K}$ & 4.57 & 12.03 & 0.1 & 10.65 & 4.43 & 11.39 & 0.14 & 0.08 & 0.58 & 42.8 & 13.23 \\
\hline V620A & 811753 & 7807036 & $22 \mathrm{~K}$ & 3.53 & 4.94 & 0.77 & 25.19 & 4.1 & 8.25 & 0.23 & 0.13 & 0.72 & 35.74 & 16.41 \\
\hline V620B & 811753 & 7807036 & $22 \mathrm{~K}$ & 5.88 & 21.52 & 0.2 & 12.02 & 6.29 & 8.69 & 0.18 & $<0.1$ & 0.85 & 38.83 & 5.54 \\
\hline V631 & 187431 & 7813503 & $23 \mathrm{~K}$ & 4.63 & 15.1 & 0.22 & 15.79 & 4.89 & 10.16 & 0.19 & 0.15 & 0.94 & 38.78 & 9.15 \\
\hline V632 & 187401 & 7815231 & $23 \mathrm{~K}$ & 4.05 & 22.43 & 0.12 & 13.81 & 4.35 & 6.92 & 0.19 & 0.15 & 0.96 & 40.03 & 6.99 \\
\hline V633A & 187490 & 7816065 & $23 \mathrm{~K}$ & 2 & 29.18 & 0.15 & 17.36 & 2.86 & 8.77 & 0.24 & 0.2 & 1.11 & 25.15 & 12.29 \\
\hline V633B & 187490 & 7816065 & $23 \mathrm{~K}$ & 6.64 & 12.17 & 0.07 & 12.85 & 6.39 & 10.56 & 0.15 & $<0.1$ & 1.32 & 45.16 & 4.69 \\
\hline V634 & 186272 & 7820493 & $23 K$ & 4.85 & 10.02 & 0.13 & 14.72 & 5.05 & 8.79 & 0.17 & 0.15 & 0.92 & 46.72 & 8.5 \\
\hline V648 & 810121 & 7814540 & $22 \mathrm{~K}$ & 6.71 & 2.34 & 0.18 & 14.85 & 6.97 & 5.6 & 0.16 & 0.18 & 0.89 & 53.88 & 8.23 \\
\hline V658 & 805109 & 7815396 & $22 \mathrm{~K}$ & 5.95 & 4.3 & 0.6 & 30.29 & 2.87 & 3.59 & 0.36 & $<0.1$ & 0.59 & 27.21 & 24.23 \\
\hline
\end{tabular}


kimberlitic and kamafugitic intrusions and clastic sedimentary rocks. Some minerals which are abundant in the Uberaba Formation are also common in the volcanic rocks of the Mata da Corda Group, such as olivine, clinopyroxene, magnetite, apatite, phlogopite and perovskite (Sgarbi et al. 2003). Freyberg (1934), studying the Capacete Formation of the Mata da Corda Group near Tiros, described a diamantiferous red conglomerate with fine matrix, which Rimann

Table 5. Whole rock analysis - rare earth element and trace elements (ppm).

\begin{tabular}{|c|c|c|c|c|c|c|c|c|c|c|c|c|c|c|c|c|c|c|c|}
\hline Samples & 7C & FU442 & FU460 & FU464 & MP01A & MP02 & V633A & V633B & V620A & V620B & V631 & V632 & V634 & V648 & V658 & HDO4 & HD05 & MP01B & MP04 \\
\hline $\mathrm{Ba}$ & 1933 & 1805 & 1248 & 1164 & 1814 & 772 & 769 & 871 & 875 & 1032 & 1854 & 745 & 857 & 924 & 925 & 1426 & 1131 & 1575 & 901 \\
\hline $\mathrm{Ce}$ & 723.1 & 983.1 & 550.9 & 996.7 & 775.7 & 824.4 & 1683 & 595.6 & 1871 & 1044 & 936.4 & 971.7 & 891.5 & 1234 & 3045 & 949.2 & 850 & 1485.1 & 1207.9 \\
\hline Co & 50.7 & 43.1 & 30.2 & 40.9 & 53.2 & 31 & 45.8 & 39.1 & 76.9 & 37.2 & 47.8 & 43.2 & 64.7 & 81.5 & 98 & 44 & 51 & 55.2 & 32.8 \\
\hline Cs & 1.24 & 0.94 & 1.17 & 1.14 & 1.06 & 0.81 & 0.63 & 1.59 & 0.69 & 1.45 & 1.26 & 0.81 & 0.99 & 1.45 & 0.52 & 1.33 & 0.84 & 0.6 & 0.5 \\
\hline $\mathrm{Cu}$ & 76 & 40 & 37 & 49 & 60 & 42 & 64 & 71 & 74 & 53 & 62 & 54 & 65 & 77 & 108 & 57 & 63 & 48.8 & 37.3 \\
\hline Dy & 9.55 & 14.13 & 8.54 & 13.61 & 8.49 & 22.03 & 35.4 & 12.63 & 20.37 & 15.64 & 12.79 & 21.44 & 10.45 & 15.95 & 74.99 & 10.81 & 12.29 & 14.81 & 13.26 \\
\hline $\mathrm{Er}$ & 3.35 & 4.12 & 3 & 4.08 & 2.42 & 5.84 & 9.46 & 4.17 & 5.42 & 4.76 & 3.84 & 5.91 & 3.19 & 5.54 & 26.48 & 3.4 & 4.27 & 3.68 & 3.16 \\
\hline $\mathrm{Eu}$ & 8.36 & 12.12 & 6.75 & 12.11 & 8.83 & 14.93 & 25.16 & 8.58 & 19.95 & 11.51 & 11.36 & 14.52 & 9.96 & 13.77 & 62.44 & 9.92 & 10.25 & 17.18 & 15.57 \\
\hline $\mathrm{Ga}$ & 13.6 & 10.8 & 11.1 & 12.8 & 12.1 & 9.6 & 12 & 15.3 & 15.9 & 12.4 & 12.1 & 10.8 & 12.6 & 16.3 & 20.9 & 12.8 & 12.4 & 9.4 & 7.8 \\
\hline $\mathrm{Gd}$ & 22.74 & 33.55 & 18.85 & 32.85 & 23.48 & 42.63 & 71.79 & 25.74 & 53.82 & 32.96 & 31.39 & 41.37 & 26.73 & 40.05 & 176.41 & 26.77 & 28.55 & 38.52 & 34.23 \\
\hline $\mathrm{Hf}$ & 13.13 & 11.34 & 9.05 & 13.18 & 9.4 & 7.07 & 10.25 & 12.37 & 13.54 & 10.73 & 12.19 & 9.42 & 10.9 & 13.3 & 15.77 & 10.88 & 11.26 & 11.5 & 10.6 \\
\hline Ho & 1.4 & 1.92 & 1.21 & 1.81 & 1.08 & 2.88 & 4.72 & 1.81 & 2.57 & 2.16 & 1.71 & 2.83 & 1.38 & 2.38 & 11.12 & 1.44 & 1.79 & 1.64 & 1.56 \\
\hline $\mathrm{La}$ & 414.3 & 423.7 & 259.9 & 483.1 & 388.1 & 210.3 & 679.5 & 255.4 & 839.6 & 348.7 & 466.3 & 349 & 464.5 & 578 & 2517 & 430.3 & 429.7 & 695.4 & 561.5 \\
\hline $\mathrm{Lu}$ & 0.3 & 0.3 & 0.26 & 0.31 & 0.18 & 0.28 & 0.39 & 0.32 & 0.31 & 0.33 & 0.26 & 0.29 & 0.24 & 0.4 & 1.99 & 0.28 & 0.27 & 0.28 & 0.25 \\
\hline Mo & $<2$ & $<2$ & $<2$ & $<2$ & $<2$ & $<2$ & $<2$ & $<2$ & $<2$ & $<2$ & $<2$ & $<2$ & $<2$ & $<2$ & $<2$ & $<2$ & $<2$ & $<0.1$ & 0.1 \\
\hline $\mathrm{Nb}$ & 304.96 & 286.66 & 150.37 & 364.61 & 244.89 & 118.53 & 421.2 & 155.8 & 638.44 & 177.11 & 311.34 & 210.58 & 291.43 & 346.08 & $>1000$ & 330.09 & 266.48 & 450.2 & 478.8 \\
\hline $\mathrm{Nd}$ & 293.5 & 372 & 215.2 & 400.8 & 307.9 & 297.2 & 652.7 & 227.2 & 704.1 & 303.6 & 369.3 & 344 & 351.3 & 460.5 & 2421 & 344.2 & 332.3 & 550.5 & 481.5 \\
\hline $\mathrm{Ni}$ & 233 & 170 & 155 & 175 & 267 & 132 & 205 & 204 & 339 & 742 & 658 & 550 & 217 & 787 & 437 & 179 & 327 & 189 & 142.3 \\
\hline $\operatorname{Pr}$ & 83.33 & 99.68 & 59.16 & 108.66 & 84.24 & 67.4 & 166.97 & 59.13 & 193.96 & 76.98 & 101.48 & 85.49 & 97.02 & 124.38 & 649.27 & 95.31 & 91.36 & 158.58 & 134.12 \\
\hline $\mathrm{Rb}$ & 100.7 & 83.7 & 82.7 & 89.4 & 83.8 & 61 & 50 & 110.6 & 66.9 & 93.5 & 84.7 & 65.4 & 79.4 & 114.1 & 44.8 & 103.3 & 88.4 & 77.6 & 52.7 \\
\hline $\mathrm{Sm}$ & 38 & 53.2 & 29.9 & 54.3 & 40.1 & 55.4 & 101.3 & 35.2 & 92.2 & 47.3 & 50.5 & 56.8 & 45.7 & 61 & 280.9 & 45.9 & 45.3 & 71.18 & 62.37 \\
\hline Sn & 3.6 & 2.9 & 1.6 & 3.3 & 2.4 & 0.8 & 2.9 & 2.1 & 5.7 & 1.9 & 3.1 & 2.5 & 2.7 & 3.1 & 8.3 & 3 & 2.9 & 4 & 3 \\
\hline Sr & 978 & 1148 & 830 & 976 & 1034 & 1634 & 2166 & 952 & 587 & 1425 & 1146 & 1360 & 1002 & 481 & 611 & 1125 & 1094 & 1312.1 & 905.6 \\
\hline $\mathrm{Ta}$ & 19.68 & 19.3 & 8.96 & 20.66 & 18.57 & 6.97 & 27.81 & 7.99 & 48.27 & 11.71 & 20.75 & 14.04 & 20.7 & 22.39 & 74.54 & 18.31 & 18.45 & 35.7 & 44.1 \\
\hline $\mathrm{Tb}$ & 2.33 & 3.52 & 2 & 3.37 & 2.26 & 4.88 & 8.02 & 2.77 & 5.38 & 3.59 & 3.14 & 4.76 & 2.66 & 3.93 & 18.04 & 2.69 & 2.95 & 3.57 & 3.41 \\
\hline Th & 46.9 & 53 & 28.3 & 63.6 & 45.8 & 25 & 79 & 23.5 & 118.9 & 39 & 51.3 & 36.6 & 50.8 & 62.9 & 216.4 & 62.6 & 47.9 & 82.8 & 95 \\
\hline $\mathrm{Tl}$ & $<0.5$ & $<0.5$ & $<0.5$ & $<0.5$ & $<0.5$ & $<0.5$ & $<0.5$ & $<0.5$ & $<0.5$ & $<0.5$ & $<0.5$ & $<0.5$ & $<0.5$ & $<0.5$ & $<0.5$ & $<0.5$ & $<0.5$ & $<0.1$ & $<0.1$ \\
\hline $\mathrm{Tm}$ & 0.38 & 0.41 & 0.33 & 0.42 & 0.24 & 0.54 & 0.83 & 0.45 & 0.51 & 0.47 & 0.4 & 0.51 & 0.33 & 0.57 & 2.77 & 0.37 & 0.42 & 0.38 & 0.4 \\
\hline $\mathrm{U}$ & 2.76 & 4.22 & 2.72 & 5.21 & 2.56 & 1.89 & 4.09 & 2.65 & 9.82 & 2.45 & 3.33 & 2.87 & 3.67 & 4.01 & 15.64 & 4.88 & 2.49 & 3.5 & 6.5 \\
\hline V & 143 & 164 & 79 & 173 & 122 & 121 & 314 & 92 & 337 & 89 & 169 & 219 & 156 & 259 & 604 & 137 & 156 & 234 & 312 \\
\hline W & 13.6 & 88.2 & 57.8 & 47.3 & 88.8 & 85.8 & 16.8 & 9.7 & 23.5 & 6.4 & 21.7 & 51.1 & 79.7 & 172.9 & 56.9 & 48.9 & 28.7 & 9 & 4.4 \\
\hline $\mathrm{Y}$ & 32.21 & 40.5 & 30.02 & 38.54 & 22.85 & 57.1 & 91.48 & 45.23 & 55.5 & 50.45 & 37.32 & 58.63 & 30.51 & 94.94 & 376.19 & 32.6 & 57.04 & 39 & 35.5 \\
\hline $\mathrm{Yb}$ & 2.4 & 2.3 & 2 & 2.4 & 1.4 & 2.6 & 3.9 & 2.6 & 2.8 & 2.7 & 2.2 & 2.7 & 1.9 & 3 & 15.5 & 2.2 & 2.2 & 2.23 & 2.43 \\
\hline $\mathrm{Zn}$ & 96 & 68 & 59 & 95 & 77 & 40 & 80 & 76 & 142 & 67 & 87 & 70 & 76 & 143 & 160 & 87 & 93 & 73 & 58 \\
\hline $\mathrm{Zr}$ & 504 & 401 & 314 & 506 & 367 & 241 & 356 & 485 & 515 & 405 & 442 & 333 & 405 & 550 & 573 & 474 & 445 & 469.7 & 429.9 \\
\hline
\end{tabular}


(1917, in Freyberg 1934) linked to kimberlite-picritic eruptive events and chrono-correlated with the Uberaba Formation. On the other hand, Batezelli and Ladeira (2016) suggest that the Capacete Formation is chrono-correlated with the Marília Formation. The ${ }^{206} \mathrm{~Pb} /{ }^{238} \mathrm{U}$ perovskite ages

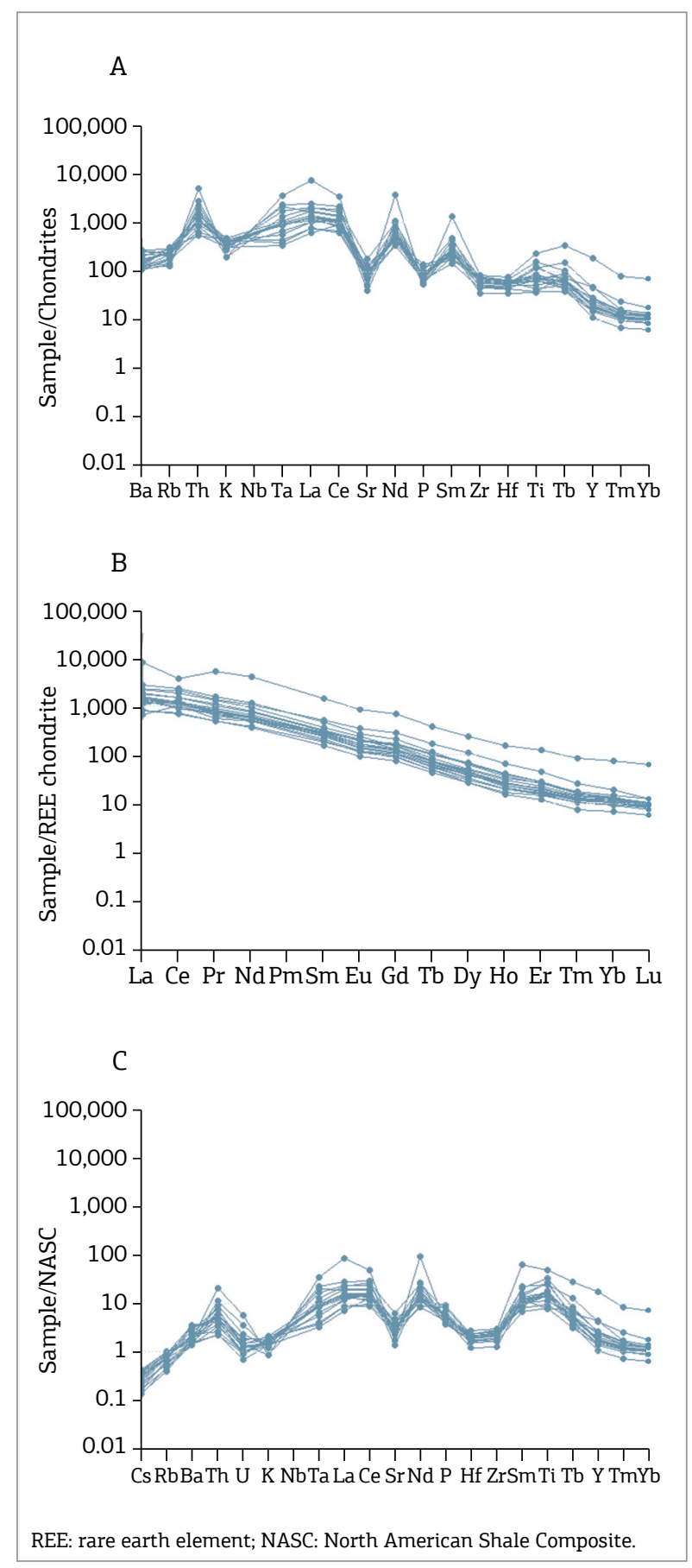

Figure 10. Whole rock geochemistry plots for samples of the Uberaba Formation: (A) trace elements, chondrite-normalized after Thompson (1982); (B) REE, chondrite-normalized after Boynton (1984); (C) REE, NASC-normalized after Taylor and McLennan (1995). of kamafugites from the Mata da Corda Group generally cluster in the 80-81 and 75-76 Ma age interval (Sgarbi et al. 2003). Thus, the Mata da Corda Group could be a correlative to the Uberaba Formation. This hypothesis needs to be checked by further geochronological studies.

We also discuss the probable chrono-correlation of the Uberaba Formation with the diamond-bearing conglomerates of the Romaria region, which outcrops $95 \mathrm{~km}$ to the northeast of Uberaba, in isolated channels carved in the basement. The conglomerates of the Romaria region are very important diamond producers, having yielded thousands of carats, including large stones. The company GAR Mineração, Comércio, Importação e Exportação LTDA. explores diamonds in the so-called Tauá conglomerate of Romaria since 2014. Some authors have proposed that this conglomerate is chrono-correlated to the Uberaba Formation, but this hypothesis remains to be proved (Ferreira Jr. 1996, Gravina et al. 2002).

According to Bizzi et al. (1991, 1993), alkaline rocks of distinct ages occur in the AP, based on Rb-Sr phlogopite ages: Santonian (117-119 Ma) and Aptian (87-86 Ma). According to Huene (1939), the Uberaba Formation was deposited during the Campanian, ca. $80 \mathrm{Ma}$ ago. Thus, this unit is contemporaneous or slightly younger than the alkaline-carbonatitic intrusion of the AP.

The anomalous concentration of clinopyroxene, plagioclase and Ti-bearing minerals in the Uberaba Formation lithic sandstones seems to be related to the erosion of the Serra Geral Formation, while schist and quartzite fragments are mostly related to the erosion of the Canastra and Araxá groups. Indeed an important component of erosion from the nearby basement, without considerable transport and sorting, is suggested by the subangulous clasts with medium sphericity.

The mineral chemistry of the Uberaba Formation detrital garnets and phlogopites are shown in Figs. 14 and 15, and compared with similar minerals in the alkaline complexes (Barbosa 2009, Brod et al. 2013) of the AP, along with mineral chemistry of samples from the Romaria region (Coelho 2010).

Chemical analyses of the detrital garnets of the Uberaba Formation indicate the presence of Ti-rich andradite, which is a common mineral in alkaline rocks (Keep \& Russell 1992). This garnet variety is present in the Tapira (Brod 1999, Eberhardt 2014) and Salitre (Barbosa 2009) complexes. Fig. $14 \mathrm{~A}$ shows a plot of $\mathrm{Mg} /(\mathrm{Mg}+\mathrm{Fe}) \times \mathrm{Ca} /(\mathrm{Ca}+\mathrm{Mg})$ in garnets (Schulze 2003), and the corresponding fields of crustal versus mantellic garnets. Most of the garnets from Romaria show a mantle affiliation, while the Uberaba Formation and alkaline complexes garnets are mainly crustal. Fig. 14B shows a $\mathrm{Mg} /(\mathrm{Mg}+\mathrm{Fe}) \times \mathrm{Cr}_{2} \mathrm{O}_{3}$ plot (Schulze 2003), in which most garnets of the Romaria conglomerate shows a peridotitic 
composition, while those from the Uberaba Formation and alkaline complexes are more like eclogitic garnets.

Studies of garnet chemistry by Dawson and Stephens (1975), Grütter (1998) and Grütter et al. (2004) led to a classification based on the $\mathrm{CaO}$ and $\mathrm{Cr}_{2} \mathrm{O}_{3}$ contents in 13 groups (G0 to G12) (Fig. 14C). G0 corresponds to garnets of dubious origin. G1 and G2 are brown megacrystals; G3, G4, G5, G6 and G8 are garnets from eclogite xenoliths; G7, G9, G11 and G12 are from lherzolite xenoliths; G10 are garnets from harzburgite and possibly diamond-bearing rocks. In the diagram of Fig. 14C (Grütter et al. 2004), garnets from Romaria are mostly within the G9 (some within the G10) group, i.e., lherzolite-derived. Garnets from the Uberaba Formation and from the alkaline complexes, on the other hand, show significative quantities of Fe, Ca and Mn (ca. 1\%), and low Cr, localized in the G3 field, from eclogitic xenoliths.

Plotting the mica analysis in a $\mathrm{Mg} \times \mathrm{Fe} \times \mathrm{Ca}$ diagram (Fig. 15a) makes possible the classification of the phlogopites. The small differences with respect to the phlogopite-annite series are due to the high Ti concentrations (mean 1.48\%). A similar situation is observed for the phlogopites of the Tapira (Brod et al. 2001) and Serra Negra (Grasso 2010) complexes (Fig. 15A). In a Fe $\times$ Mg plot (Fig. 15B) the samples plot within the alkaline complexes trend. A subordinate substitution of $\mathrm{Mg}$ to Fe can be identified in this plot. According to Cordeiro et al. (2010), this substitution occurs in the Cataláo I Complex and indicates distinct zoning patterns in the micas of the different rocks of the complex. The compositional variation of the $\mathrm{Al}_{2} \mathrm{O}_{3}$ and $\mathrm{TiO}_{2}$ grades in micas, plotted in Fig. 15C, reflects the high grades of $\mathrm{TiO}_{2}$ and low $\mathrm{Al}_{2} \mathrm{O}_{3}$, a signature that is similar to the one of the alkaline complexes.

Finally, a $\mathrm{Ti} \times[\mathrm{Fe} /(\mathrm{Fe}+\mathrm{Mg})]$ diagram (Fig. 15D) shows the high Ti grades in analyzed phlogopites. This is accompanied by a raise in $\mathrm{Fe} /(\mathrm{Fe}+\mathrm{Mg})$, a pattern which is very similar to that of phlogopites of the AP alkaline complexes.
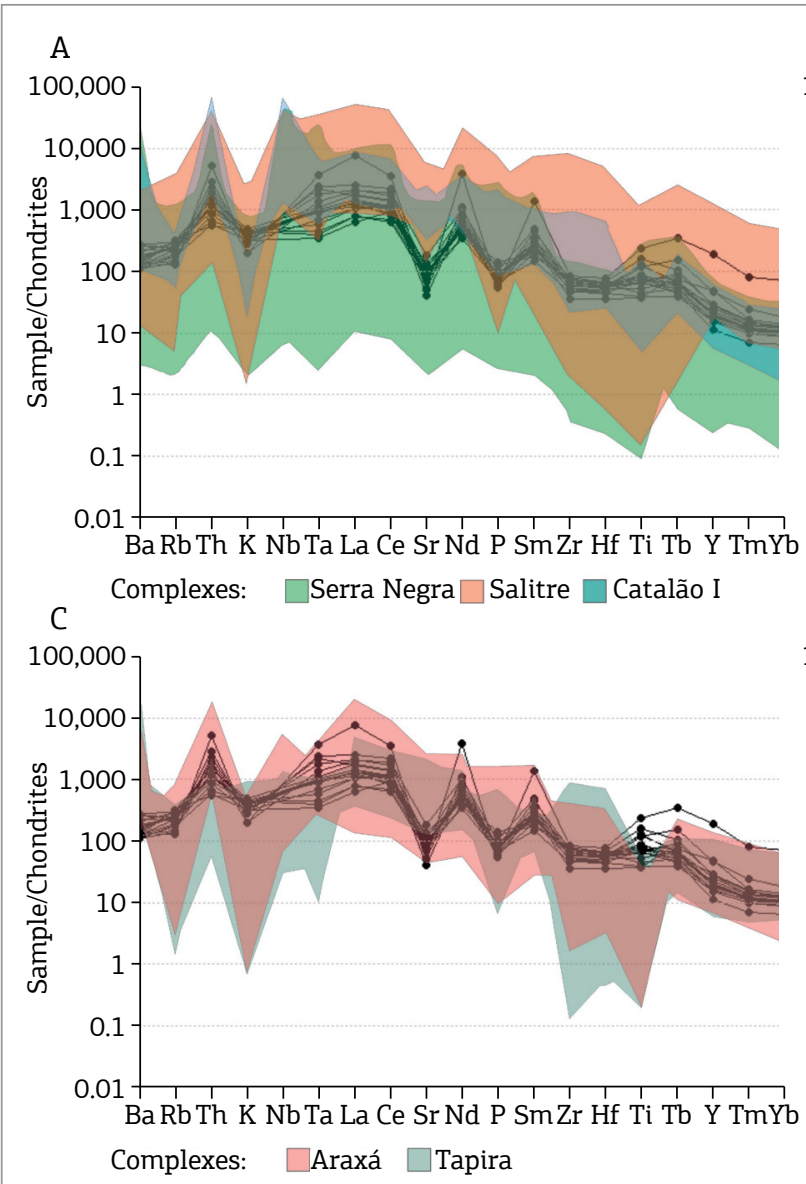

\section{$\mathrm{B}$}

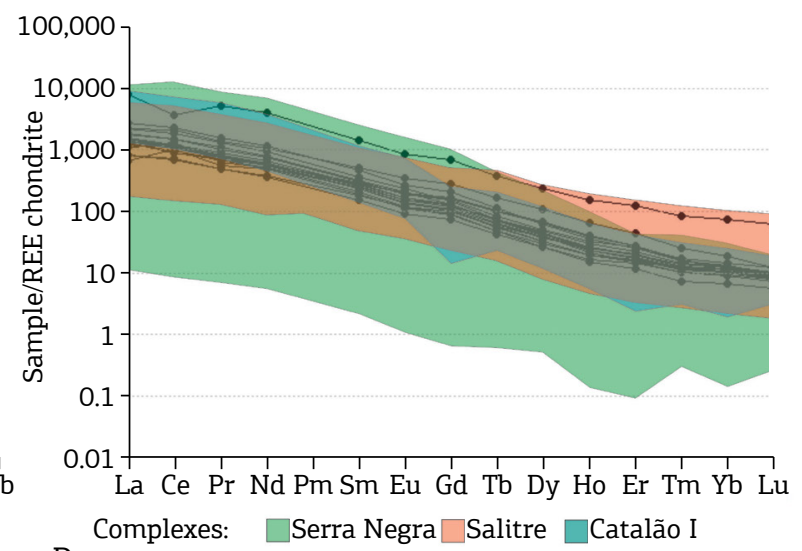

$\mathrm{D}$

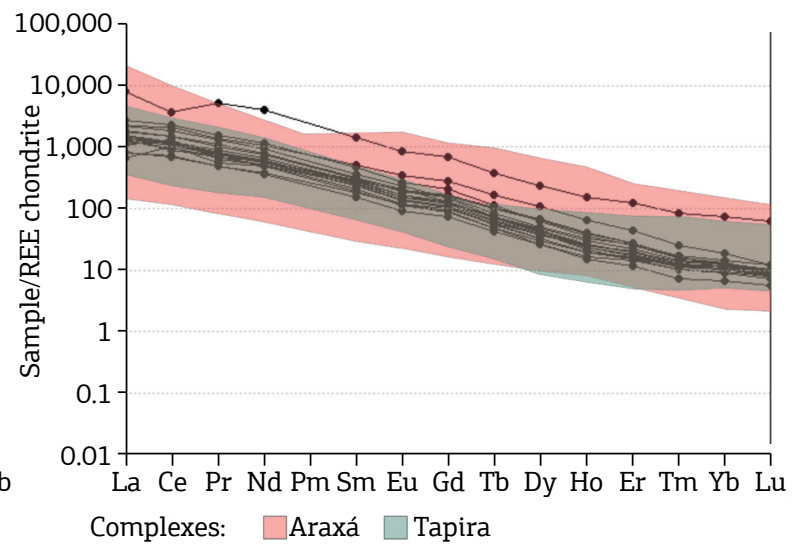

REE: rare earth element.

Figure 11. Compared whole rock geochemistry of the Uberaba Formation (line graphics) and AP alkaline complexes: (A) trace elements and (B) REE, chondrite-normalized after Thompson (1982) for the following alkaline complexes: Serra Negra (Grasso 2010), Salitre (Barbosa 2009) and Catalão I (Cordeiro et al. 2010); (C) trace elements and (D) REE, chondrite-normalized after Boynton (1984) for the following alkaline complexes: Araxá (Traversa et al. 2000) and Tapira (Brod et al. 2013). 
Whole rock chemistry analyses of the Uberaba Formation sandstones also suggest a high influence of the alkaline complexes as source areas. This is mainly expressed in the high overall REE concentrations, heavily fractionated LREE, flat REE chondrite-normalized patterns (no Eu anomaly), $\mathrm{Ta}-\mathrm{Nb}$ positive anomalies, and high $\mathrm{Ti}$ and $\mathrm{Th}$ concentrations from perovskite, a rare mineral in detrital rocks, but common in alkaline complexes.

The complexes of Serra Negra, Catalão I, Salitre, Araxá and Tapira share all of those characteristics, with high REE concentrations, fractionated LREE, Nb-Ta positive anomalies, etc. (Fig. 11). The smaller complexes, such as Catalão I, Araxá and Tapira, show little variation of the element concentrations resulting in limited fields in the plots (Fig. 11). The larger complexes, such as Serra Negra and Salitre, on the other hand, show a greater variability, leading to broader plotting fields (Fig. 11A and B).

Thus, between the studied complexes, the ones that most closely resemble the geochemical patterns of the Uberaba Formation are those of Cataláo I and Tapira (Fig. 11C and D). The main difference is the negative $\mathrm{Sr}$ anomaly of the Uberaba Formation, which might be related to the leaching of this element
A

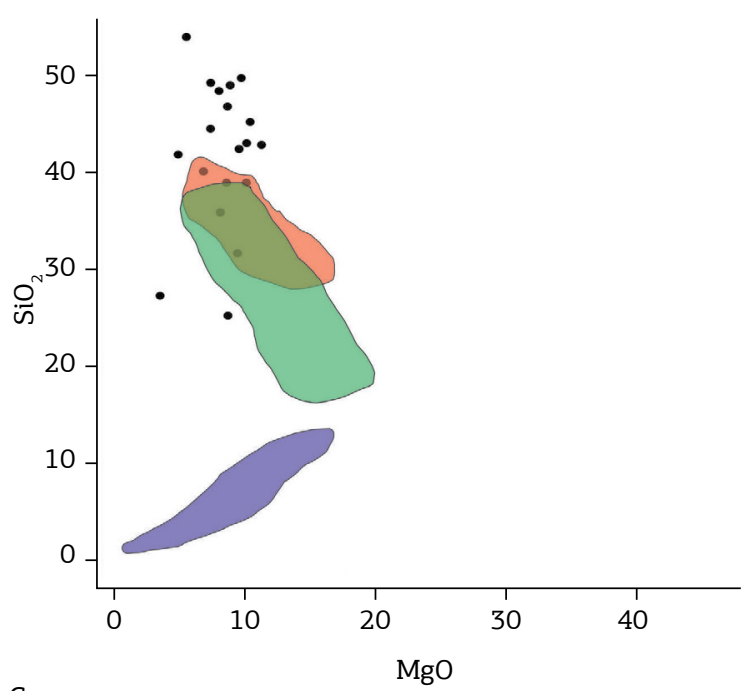

C

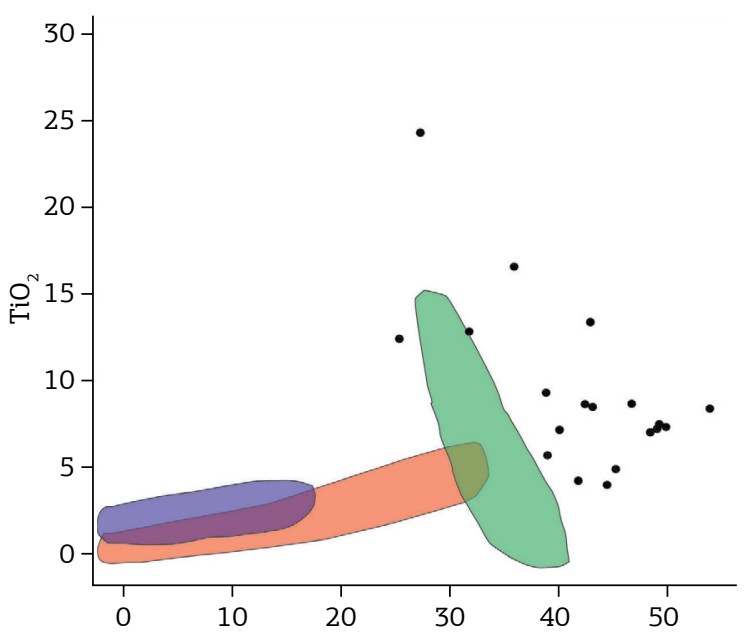

B

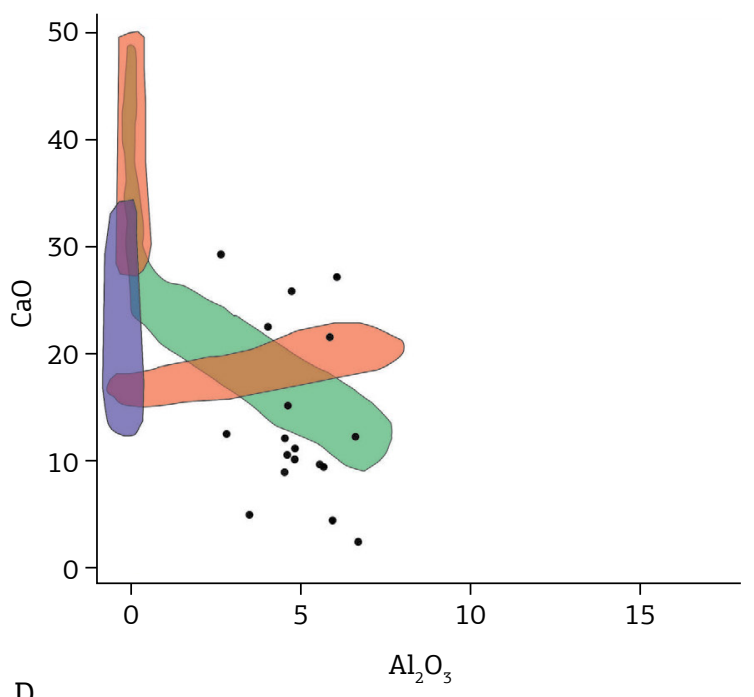

D

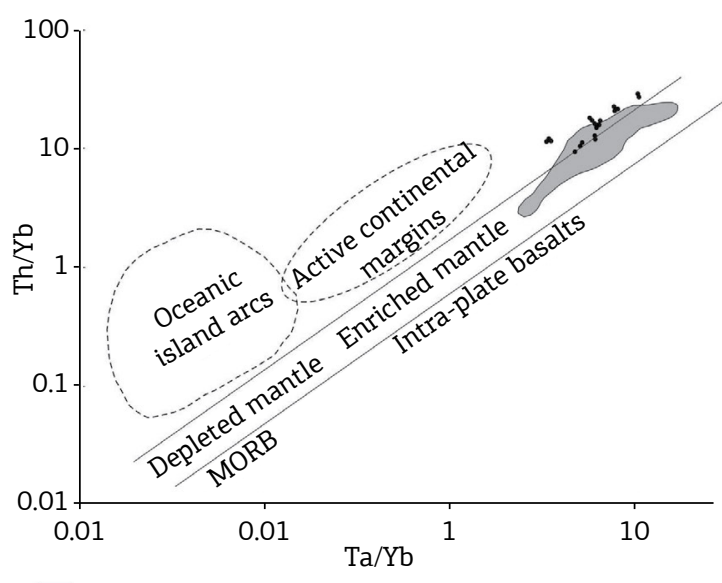

High Paranaíba Alkaline Complexes
Legend

Serra Negra and Salitre Complexes

- Uberaba Formation
Tapira and Araxá Complexes

Catalão I Complex

Figure 12. Geochemistry diagrams comparing the Uberaba Formation with AP alkaline complexes, in (A) $\mathrm{SiO}_{2} \times \mathrm{MgO},(\mathrm{B}) \mathrm{CaO} \times \mathrm{Al}_{2} \mathrm{O}_{3}$, (C) $\mathrm{TiO}_{2} \times \mathrm{SiO}_{2}$ and (D) $(\mathrm{Th} / \mathrm{Yb}) /(\mathrm{Ta} / \mathrm{Yb})$. 


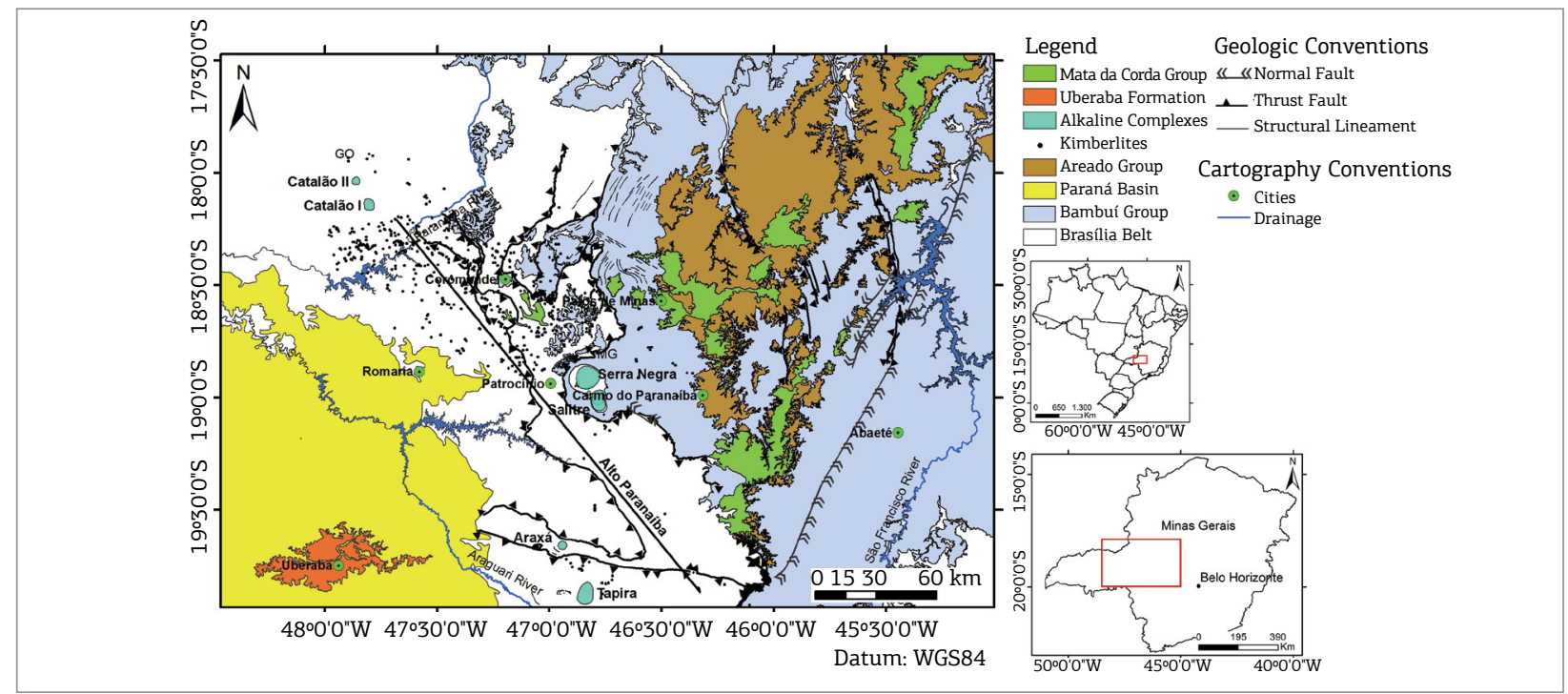

Figure 13. Geologic map of the AP (Alto Paranaíba). Adapted from Oliveira et al. (2004), with the locations of the alkaline complexes and the distribution of the Uberaba Formation.

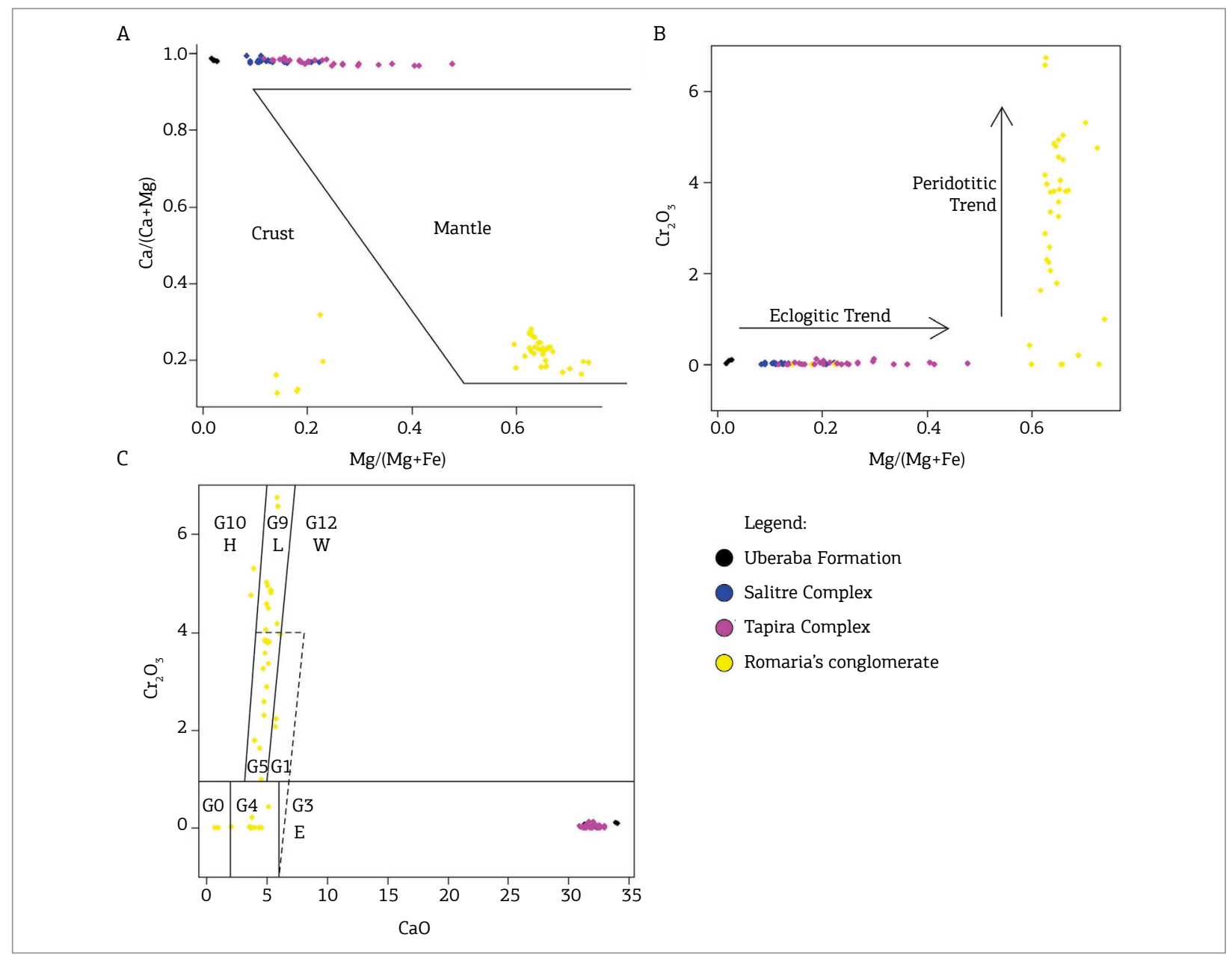

Figure 14. Mineral chemistry binary diagrams of garnets from Uberaba Formation comparing with garnets from alkaline complexes and from Romaria's diamantiferous conglomerate (Tauá): $(\mathrm{A})[\mathrm{Mg} /(\mathrm{Mg}+\mathrm{Fe})] \times[\mathrm{Ca} /(\mathrm{Ca}+\mathrm{Mg})]$ diagram after Schulze (2003) separating mantle-affiliation and crust-affiliation garnets; (B) $\mathrm{Mg} /(\mathrm{Mg}+\mathrm{Fe}) \times \mathrm{Cr}_{2} \mathrm{O}_{3}$ diagram after Schulze (2003) classifying garnet's evolutionary trends and (C) $\mathrm{CaO} \times \mathrm{Cr}_{2} \mathrm{O}_{3}$ diagram after Grütter et al. (2004) classifying garnet's provenance, H: harzburgite, L: lherzolite, W: werhlite and E: eclogite). Salitre mineral chemistry analysis from Barbosa (2009), Tapira from Brod et al. (2013) and Romaria from Coelho (2010). 
during the carbonatic/dolomitic cementation. On the other hand, enrichment in Ti and Th is related to detrital perovskite.

According to Mitchell (1986), garnets are important indicators in the identification of kimberlites and their magma sources. The results obtained for detrital garnets of the Uberaba Formation confirm the presence of andradite garnet, of the schorlomite variety, which is rich in $\mathrm{Ti}$, thus not indicating a kimberlitic source, as suggested by the plotting of the garnets in the eclogitic xenolith field in Fig. 14B. The contrary is observed in Romaria pyrope garnets, which indicate a kimberlitic source. Compared to the diamond-bearing conglomerates of Romaria, the Uberaba Formation provenance and sourcing is quite distinct (Fig. 14C).

\section{CONCLUSIONS}

According to the stratigraphic, petrographic, mineral chemistry and whole-rock geochemical data gathered for the Uberaba Formation, three main source areas can be
A

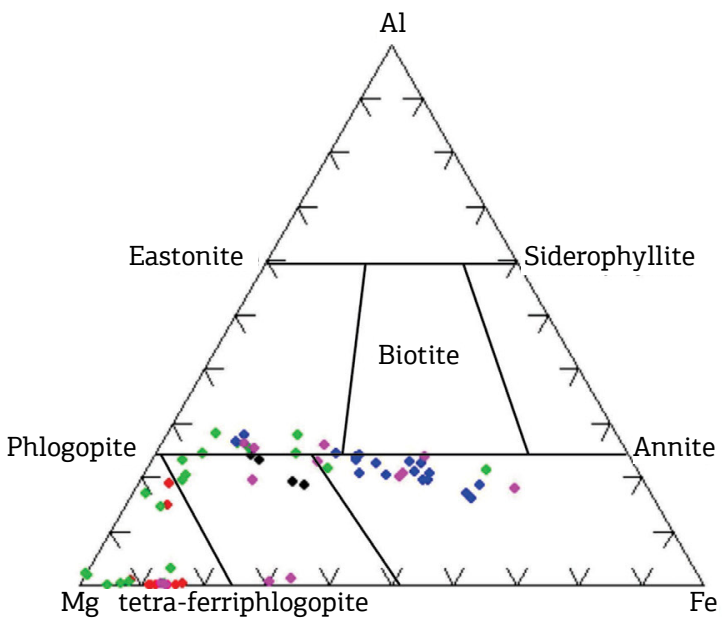

C

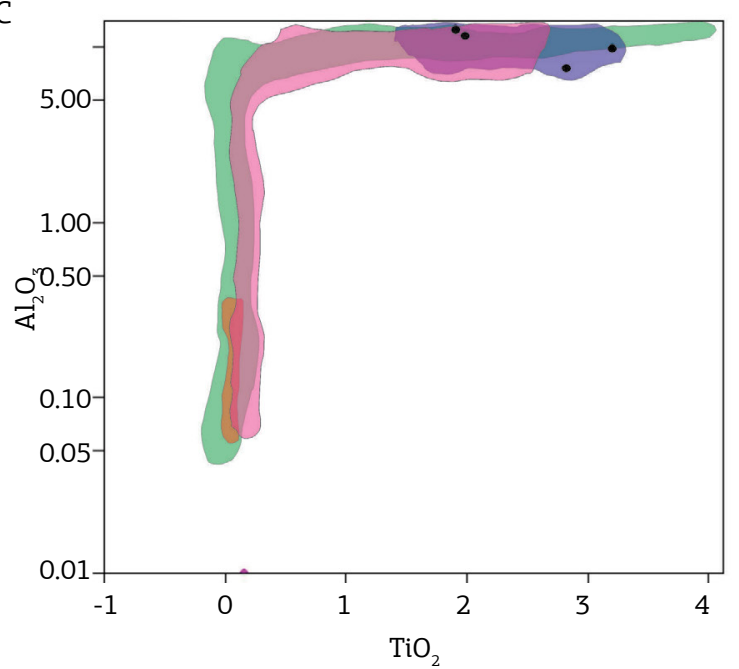

Legend for figure (a):

- Uberaba Formation

Salitre Complex

Catalão I Complex
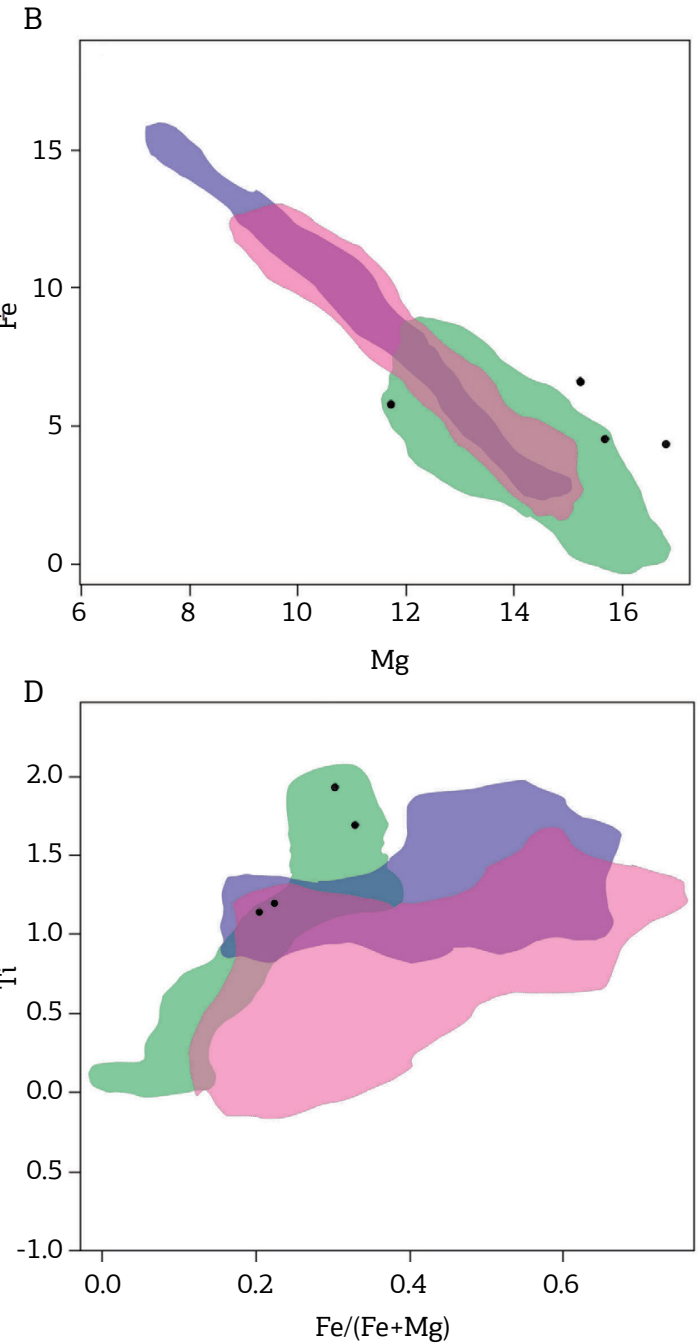

Legend for figures (b), (c) and (d):

$\square$ Salitre Complex $\square$ Tapira Complex

Catalão I Complex

Uberaba Formation

Figure 15. Mineral chemistry binary and ternary diagrams of phlogopites from the Uberaba Formation compared to phlogopites from some alkaline complexes of the AP: (A) $\mathrm{Mg} \times \mathrm{Fe} \times \mathrm{Ca}$ ternary diagram of micas classification; binary diagrams comparing phlogopites chemistry according to (B) $\mathrm{Fe} \times \mathrm{Mg},(\mathrm{C}) \mathrm{Al}_{2} \mathrm{O}_{3} \times \mathrm{TiO}_{2}$ e (D) $\mathrm{Ti} \times[\mathrm{Fe} /(\mathrm{Fe}+\mathrm{Mg})]$. 
recognized for the provenance of the lithic sandstones and conglomerates of this unit, which probably represents a braided fluvial system:

1. Precambrian rocks of the Araxá and Canastra groups;

2. basalts of the Serra Geral Formation;

3. alkaline rocks of the Catalão I, Catalão II, Serra Negra, Salitre, Tapira, and Araxá cretaceous intrusions and others similar rocks.

All of those units are exposed in the AP Arch, a basement high to the east of the Uberaba Formation outcrop area, which has been active during the Cretaceous.

The chemical composition of the Uberaba Formation rocks, which is very similar to that of the alkaline complexes (highly fractionated REE with $\mathrm{La}_{\mathrm{N}} / \mathrm{Yb}_{\mathrm{N}}=$ ca. 128; positive $\mathrm{Nb}-\mathrm{Ta}$ and $\mathrm{Ba}$ anomalies), and abundant detrital perovskite, suggests that the third source area was somewhat preponderant over the other two ones. The unit might also involve some syn-sedimentary volcanic or volcanoclastic activity as suggested by a greenish very fine matrix in some samples and fragments of quartz with corroded gulfs.

The chemical analysis of perovskite, garnet and phlogopite confirms that those minerals show similar composition as those ones found in the alkaline complexes of the AP. Garnets of the Uberaba Formation are mainly schorlomite, a Ti-rich variety of andradite, and plot in the field of eclogitic xenoliths (crustal garnets) in discriminatory diagrams. Thus, the unit is not prone to bear detrital diamond grains, as garnets are not indicative of a kimberlitic (mantellic) affiliation.

A chronocorrelation of the Uberaba Formation and the Mata da Corda Group, of around 80-75 Ma (Sgarbi et al. 2003) can be considered for investigation. The diamond-bearing Romaria conglomerate, however, shows a very distinct provenance pattern, bearing pyrope garnets which fall within the kimberlitic field in discriminatory diagrams. Thus, the Uberaba Formation is probably not correlated to the Romaria conglomerate. The geochemical and mineral chemistry features suggest that the Uberaba Formation was not a likely source for alluvial diamonds of the southeastern TM region. Thus, the quest for the source of those diamonds remains open.

\section{ACKNOWLEDGMENTS}

Companhia do Desenvolvimento do Estado de Minas Gerais (CODEMIG) and Centro de Pesquisas Manoel Teixeira da Costa (CPMTC-IGC-UFMG), for financial and logistic support through the Triângulo Mineiro mapping project 2015/2017. Complexo Cultural e Científico de Peirópolis/Universidade Federal do Triângulo Mineiro, in Uberaba (MG), team for the lodging. The manuscript was greatly improved after comments and suggestions by G. Basilici and F. Vesely.

\section{REFERENCES}

Almeida F.F.M. \& Barbosa O. 1953. Geologia das quadrículas de Piracicaba e Rio Claro. Boletim da Divisão de Geologia e Mineralogia, 143:1-96.

Barbosa O. 1934. Resumo de geologia do Estado de Minas Gerais. Departamento de Serviço Geográfico e Geológico. In: Boletim 3, 40p. Minas Gerais

Barbosa O., Braun O.P.C., Dyer R.C., Cunha C.A.B.R. 1970. Geologia da região do Triângulo Mineiro. In: Boletim 136, Rio de Janeiro. DNPM/ DFPM. 140p.

Barbosa E.S R. 2009. Mineralogia e petrografia do complexo carbonatítico foscorítico de Salitre, MG. Tese - Instituto de Geociências, Universidade de Brasília, Brasília. 432p.

Barcelos J.H. 1984. Reconstrução Paleogeográfica da Sedimentação do Grupo Bauru Baseada na sua Redefinição Estratigráfica Parcial em Território Paulista e no Estudo Preliminar Fora do Estado de São Paulo. Tese - Instituto de Geociências e Ciências Exatas, Universidade Estadual Paulista "Júlio de Mesquita Filho", Rio Claro. 190p.

Barcelos J.H. 1989. Influência do Soerguimento do Alto Paranaíba na Sedimentação Pós-Basáltica na Área do Triângulo Mineiro (MG), Borda NNE da Bacia do Paraná. Geociências, 8:38-54.

Batezelli A. 2003. Análise da sedimentação cretácea no Triângulo Mineiro e sua correlação com áreas adjacentes. Tese - Universidade Estadual Paulista "Júlio de Mesquita Filho", Rio Claro. 195p.
Batezelli A. \& Ladeira F.S.B. 2016. Stratigraphic framework and evolution of the Cretaceous continental. Journal of South American Earth Sciences, 65:1-24.

Bertini R.J. 1993. Paleobiologia do Grupo Bauru, Cretáceo Superior continental da Bacia do Paraná, com ênfase em sua fauna de amniotas. Tese - Instituto de Geociências, Universidade Federal do Rio de Janeiro, Rio de Janeiro. 493p.

Bizzi L.A., Smith C.B., Meyer H.O.H., Armstrong R., De Wit M.J. 1991. Mesozoic kimberlites and related rocks in southwestern São Francisco Craton, Brazil: a case for local mantle reservoirs and their interaction. $8^{\text {th }}$ International Kimberlite Conference. Extended Astracts. Victoria, Canada. p.17-19.

Bizzi L.A., De Wit M.J., Smith C.B., Armstrong R.A. 1993. Características isotópicas e origem dos kimberlitos e vulcânicas alcalinas relacionadas em Minas Gerais. In: Simpósio Brasileiro sobre a Geologia do Diamante, Brasil. Geol. Diamante. 1. In: Anais... Cuiabá, UFMT Publ. Esp. 2/93, p. 141-151.

Boynton W.V. 1984. Cosmochemistry of the rare earth elements: meteoritic studies. In: Henderson, P. (ed.). Rare Earth Elements Geochemistry. Amsterdam: Elsevier, p. 63-114.

Brod, J.A. 1999. Petrology and Geochemistry of the Tapira Alkaline Complex, Minas Gerais State, Brazil. Tese - University of Durham, Durham. 500p. 
Brod J.A., Gaspar D.P., Araújo D.P., Gibson S.A., Thompson R.N. Junqueira-Brod T.C. 2001. Phlogopite and tetra-ferriphlogopite from Brazilian carbonatite complexes: petrogenetic constraints and implications for mineral-chemistry systematics. Journal of Asian Earth Sciences, 19:265-296.

Brod J.A., Junqueira-Brod T.C., Gaspar J.C., Petrinovic I.A., Valente S.C., Corval A. 2013. Decoupling of Paired Elements, Crossover REE Patterns, and Mirrored Spider Diagrams: Fingerprinting Liquid Immiscibility in The Tapira Alkaline Carbonatite Complex, SE Brazil. Journal of South American Earth Sciences, 41:41-56.

Bryon J.M. 1999. Physical Volcanology and Lithogeochemistry of Mata da Corda Formation, Minas Gerais, Brazil. Tese - Carleton University, Ontario. 297p.

Campos L.F. 1891. Jazidas Diamantíferas de Água Suja (Bagagem) Estado de Minas Gerais. Rio de Janeiro: Typ. Ed. Fluminense.

Coelho F.M. 2010. Aspectos geológicos e mineralógicos da Mina de diamantes de Romaria, Minas Gerais. MS Dissertation, Universidade de São Paulo, São Paulo. 106p.

Cordeiro P.F.O., Brod J.A., Dantas E.L., Barbosa E.S.R. 2010. Mineral Chemistry, Isotope Geochemistry and Petrogenesis of Niobium-Rich Rocks From The Catalão I Carbonatite-Phoscorite Complex, Central Brazil. Lithos, 118:223-237.

Costa M.T. 1963. Estrutura geológica dos cerrados. Departamento de Pesquisas e experiências Agropecuárias, Ministério da Agricultura, Bolívia, 15

Dawson J.B. \& Stephens W.E. 1975. Statistical classification of garnets from kimberlites and associated xenoliths. Journal of Geology, 83:589-607.

Deer W.A., Howie R.A., Zussman J. 1992. An Introduction to the Rock Forming Minerals. $2^{\text {nd }}$ ed. London: Longman. 696p.

Eberhardt D.B. 2014. Elementos-Traços em Minerais do Complexo Alcalino Carbonatítico de Tapira - MG. MS Dissertation Universidade de Brasília, Brasília. 148p.

Fernandes L.A. \& Coimbra A.M. 2000. Revisão Estratigráfica da Parte Oriental da Bacia Bauru (Neocretáceo). Revista Brasileira de Geociências, 30(4):717-728.

Fernandes A.F., Karfunkel J., Hoover D.B., Sgarbi G.N.C., Walde D., Gomes J., Kambrock K. 2014. The Basal Conglomerate of the Capacete Formation (Mata Da Corda Group) and its Relation to Diamond Distributions in Coromandel, Minas Gerais State, Brazil. Brazilian Journal of Geology, 44:91-103.

Fernandes L.A., Ribeiro C.M.M. 2015. Evolution and palaeoenvironment of the Bauru Basin (Upper Cretaceous, Brazil). Journal of South American Earth Sciences, 61:71-90.

Ferreira V.G., Quintão D.A., Caxito F.A., Bittencourt J., Ribeiro L. C. B. (in press). Mapa Geológico da Folha Veríssimo-Miguelópolis, escala 1:100.000. Belo Horizonte, Projeto de Mapeamento Geológico CODEMIG/UFMG2015-17.

Ferreira Jr. P.D. 1996. Modelo Deposicional e Evolução Diagenética da Formação Uberaba, Cretáceo Superior da Bacia do Paraná, na Região do Triângulo Mineiro. MS Dissertation - Universidade Federal de Ouro Preto, Ouro Preto. 175p.

Ferreira Jr. P.A. \& Gomes N.S. 1999. Petrografia e Diagênese da Formação Uberaba, Cretáceo Superior da Bacia do Paraná no Triângulo Mineiro. Revista Brasileira de Geociências, 29(2):163-172.

Ferreira Jr. P.D. \& Guerra W.J. 1993. Estudo preliminar sobre o ambiente deposicional da Formação Uberaba. In: 7.0 Simpósio de Geologia de Minas Gerais. Belo Horizonte. In: Anais... Belo Horizonte, SBG/MG, p. 17-21.
Ferreira Jr. P.D. \& Guerra W.J. 1995. Análise de elementos arquiteturais na caracterização do sistema fluvial da Formação Uberaba, Cretáceo Superior da Bacia do Paraná no Triângulo Mineiro. In: 8. Simpósio de Geologia de Minas Gerais, Diamantina, 1995. In: Anais... Diamantina, SBG/MG, p. 104-106.

Foley S.F., Venturelli G., Green D.H., Toscani L. 1987. The ultrapotassic rocks - characteristics, classification, and constraints for petrogenetic models. Earth-Science Reviews, 24:81-134.

Freyberg B.Von. 1934. Die Bodenschätze des Staates Minas Gerais (Brasilien). E. Schweizerbart'sche Verlagsbuchhandlung. Erwin Nägeli. 453p

Fulfaro V.J. \& Barcelos J.H. 1991. Grupo Bauru no Triângulo Mineiro: Uma Nova Visão Litoestratigráfica. In: 2. ${ }^{\circ}$ Simpósio de Geologia do Sudeste, São Paulo. Atas... São Paulo, SBG/SP-RJ, p.59-66.

Goldberg K. 1995. Reconstituição Paleoambiental do Cretáceo Continental Brasileiro na região do Triângulo Mineiro. MS Dissertation - Universidade do Vale do Rio dos Sinos, São Leopoldo. 181p

Grasso C.B. 2010. Petrologia do complexo alcalino-carbonatítico de Serra Negra, MG. MS Dissertation - Instituto de Geociências, Universidade de Brasília, Brasília. 164 p.

Gravina E.G., Kafino C.V., Brod J.A., Boaventura G.R., Santos R.V., Guimarães E.M., Jost H. 2002. Proveniência de arenitos das formações Uberaba e Marília (Grupo Bauru) e do Garimpo Bandeira: Implicações para a controvérsia sobre a fonte do diamante do Triângulo Mineiro. Revista Brasileira de Geociências, 32(4):545-558

Grütter H.S. 1998. Chrome-calcium, magnesium-number and yttrium characteristics of garnets in depleted lherzolitic, harzburgitic and duniticc mantles. Extended Abstracts. In: $7^{\text {th }}$ International Kimberlite Conference, Cape Town, South Africa, p. 277-279.

Grütter H.S., Gurney J.J., Menzies A.H., Winter F. 2004. An updated classification scheme for mantle-derived garnet, for use by diamond explorers. Lithos, 77:841-857.

Guimarães D. 1964. Geologia do Brasil. Memoria N.o 1. DNPM, 674p. Rio de Janeiro.

Hasui Y. 1968. A Formação Uberaba. In: 22. ${ }^{\circ}$ Congresso Brasileiro de Geologia, Belo Horizonte. Anais... Belo Horizonte, SBG, p. 167-179.

Huene F.Von. 1939. Carta de F.von Huene ao Dr. Euzébio de Oliveira. Mineração e Metalurgia, Rio de Janeiro, 4(22):190.

Hussak E. 1891. Notícia dos Minerais das Areias Diamantíferas da Bagagem de Água Suja. Rio de Janeiro: Typ. Da Cia Ed. Fluminense. p. 21-25

Hussak E. 1906. Rocha Tufácea de Uberaba, Rico em Perowiskita. Zeitschrift für Prakitische Geologie, Jg., 16:322-324.

Karfunkel J., Hoover D., Fernandes A.F., Sgarbi G.N.C., Krambrock K., Oliveira, G.D. 2014. Diamonds from the Coromandel Area, West Minas Gerais State, Brazil: an update and new data on surface sources and origin. Brazilian Journal of Geology, 44(2):325-338.

Karfunkel J., Hoover D.B., Fernandes A.F., Norberto G.C.S., Kambrock K., Walde D., Michelfelder G. 2015. Surface source of Coromandel diamonds (Minas Gerais State, Brazil) and their possible origin from the Serra Negra/Salitre Supervolcano. Neues Jahrbuch für Geologie und Paläontologie, 277(2):237-250.

Keep M. \& Russell J.K. 1992. Mesozoic alkaline rocks of the Averill plutonic complex. Canadian Journal of Earth Sciences, 29:2508-2520.

Milani E.J., Melo J.H.G., Souza P.A., Fernandes L.A., França A.B. 2007. Bacia do Paraná. Boletim de Geociências da Petrobras, 15(2):265-287.

Mitchell R.H. 1986. Kimberlites. Mineralogy, Geochemistry, and Petrology. Plenum Press, New York, 442 p. 
Oliveira I.W.B., Sachs L.L.B., Silva V.A., Batista I.H. 2004. Folha SE.23Belo Horizonte. In: Schobbenhaus C., Gonçalves J.H., Santos J.O.S., Abram M.B., Leão Neto R., Matos G.M.M., Vidotti R.M., Ramos M.A.B., Jesus J.D.A. (Editors). Carta geológica do Brasil ao millionésimo: Sistema de Informações Geográficas - SIG e 46 folhas na escala 1: 1.000.000. Brasília: CPRM. 41 CD-ROM Pack.

Rimann E. 1917. A Kimberlita no Brasil. Anais da Escola de Minas de Ouro Preto, 15:27-32.

Sad G.J.H. 1970. Complexos silicocarbonatíticos da região do Alto Paranaíba, Brasil Meridional. In: 24. ${ }^{\circ}$ Congresso Brasileiro de Geologia, Brasília. Resumo das conferências e comunicações, SBG, p. 16-19.

Santucci R.M. \& Bertini R.J. 2001. Distribuição Paleogeográfica e Biocronológica dos Titanossauros (Saurish, Sauropoda) do Grupo Bauru, Cretáceo Superior do Sudeste Brasileiro. Revista Brasileira de Geociências, 31(3):307-315.

Schulze D.J. 2003. A Classification Scheme for Mantle-Derived Garnets in Kimberlite: A Tool for Investigating The Matle and Exploring for Diamonds. Lithos, 71:195-213.

Seer H. \& Moraes L.C. (in press). Mapa Geológico da Folha Uberaba, escala 1:100.000. Belo Horizonte, Projeto de Mapeamento Geológico CODEMIG/UFMG2015-17.

Sgarbi P.B.A., Heaman L.M., Gaspar J.C. 2003. U-Pb Perovskite Ages for Brazilian Kamafugitic Rocks: Further Support for a Temporal Link to a Mantle Plume Hotspot Track. Journal of South American Earth Sciences, 16:715-724.

Silva R.B. de, Etchebehere M.L. de C., Saad A. R. 1994. Groundwater Calcretes: Uma Interpretação Alternativa para os Calcários da Formação Marília no Triângulo Mineiro. In: 3. o Simpósio Sobre o Cretáceo do Brasil, Rio Claro, São Paulo. Boletim... Brasil, p. 85-90.
Soares P.C., Landim P.M.B., Fulfaro V.J., Sobreiro Neto A.F. 1980. Ensaio de caracterização estratigráfica do Cretáceo no Estado de São Paulo: Grupo Bauru. Revista Brasileira de Geociências, São Paulo, 10(3):177-185.

Suguio K. 1980. Fatores Paleoambientais e Paleoclimáticos, e Subdivisão Estratigráfica do Grupo Bauru. In: Mesa-Redonda A Formação Bauru no Estado de São Paulo e Regiões Adjacentes, São Paulo. Coletânea de trabalhos e debates. São Paulo: SBG, p. 15-30 (Publicação Especial, 7).

Tamrat E., Ernesto M., Fulfaro V.J., Saad A.R., Batezelli A., Oliveira A.F. 2002. Magnetoestratigrafia das formações Uberaba e Marília (Grupo Bauru) no Triângulo Mineiro (MG). In: 6. o Simpósio sobre o cretáceo do Brasil e 2. ${ }^{\circ}$ Simpósio sobre el creácico de América del Sur, São Pedro. Boletim... São Pedro, p. 323-327.

Taylor S.R. \& McLennan S.M. 1995. The geochemical evolution of the continental crust. Reviews of Geophysics, 33:241-265.

Thompson R.N. 1982. Magmatism of the British Tertiary Volcanic Province. Department of Geology, Imperial College of Science and Technology, London.

Traversa G., Gomes C.B., Brotzu P., Buraglini N., Morbidelli L., Principato S.R., Ruberti E. 2000. Petrography and Mineral Chemistry of Carbonatites and Mica-Rich Rocks From The Araxá Complex (Alto Paranaíba Province, Brazil). Anais da Academia Brasileira de Ciências, 73(1):71-98.

Wilson M. 1989. Igneous Petrogenesis - A Global Tectonic Approach. London: Harper Collins. 466p.

Available at www.sbgeo.org.br 